\title{
13
}

\section{The Effects of Water Quality Characteristics on Pollutant Releases from Drainage Materials}

\author{
Olga N. Ogburn, Robert E. Pitt and Shirley E. Clark
}

Over the last twenty years it has become recognized that the leaching of heavy metals (mainly zinc) from roofing materials is a significant source of heavy metals in stormwater (He et al., 2001a). Field studies have been conducted to quantify the metal release rates from various roofing materials, including new and naturally aged copper and zinc sheeting under different atmospheric conditions (Clark, Long et al., 2008; Clark, Steele et al., 2008; He, 2002; He et al., 2001a; 2001b; Odnevall Wallinder et al., 2002; Odnevall Wallinder et al., 2009; Veleva et al., 2010). Roof runoff heavy metal discharges have been found to be an important factor in the degradation of water quality in urban receiving waters (Burton and Pitt, 2002; NRC, 2008; Pitt et al., 1995). The drainage system components of roofs are frequently constructed of metals, including aluminum, zinc, lead and copper. These heavy metals can be found in potentially high concentrations (ranging from hundreds of $\mu \mathrm{g} / \mathrm{L}$ to tens of $\mathrm{mg} / \mathrm{L}$ ) in roof runoff (Clark et al., 2007; Clark, Long et al., 2008; Clark, Steele et al., 2008; Forster, 1996; Morquecho, 2005; Odnevall Wallinder, 2001; Pitt et al., 1995; Tobiason. 2004; Good 1993).

Studies conducted by previous researchers indicate that the contamination of roof runoff is dependent on the type of roofing materials used and the quality of the rainfall (Clark, Long et al., 2008; Clark, Steele et al., 2008; Corvo et al., 2005; Faller and Reiss, 2005; NRC, 2008; Odnevall Wallinder et al., 2000; Odnevall Wallinder et al., 2001; Veleva et al., 2010). Fewer studies have also investigated pipe materials and how they affect water quality and factors that affect heavy metal release (Al-Malack et al., 2001; Lasheen et al.,

Ogburn, O., R.E. Pitt and S. Clark. 2013. "The Effects of Water Quality Characteristics on Pollutant Releases from Drainage Materials." Journal of Water Management Modeling R246-13. doi: 10.14796/JWMM.R246-13.

(C) CHI 2013 www.chijournal.org ISSN: 2292-6062 (Formerly in Pragmatic Modeling of Urban Water Systems. ISBN: 978-0-9808853-8-5) 
2008; Lagos et al., 2001; Edwards et al., 1996; Edwards et al., 2001; Merkel et al., 2002; Pehkonen, 2002; Mansouri et al., 2003; Schock et al., 1995; USEPA, 1995; Boulay and Edwards, 2001).

The purpose of this study was to investigate heavy metal releases from different pipe, gutter and storage tank materials under a wide range of environmental conditions. The influences of $\mathrm{pH}$, salinity and time of contact were examined. Knowledge of the quantity of the pollutants released by gutter and piping materials will facilitate the selection of drainage system components (and building materials) that have minimal environmental effects.

Two series of static long term leaching laboratory tests were conducted, each over 3 month periods, using eight new gutter and pipe materials. The first set of experiments were conducted to investigate heavy metal releases under controlled high and low $\mathrm{pH}$ conditions. The materials were immersed in locally collected roof runoff and parking lot runoff that were adjusted to $\mathrm{pH} 5$ and $\mathrm{pH} 8$ using buffer chemicals added to the runoff water (disodium phosphate dehydrate and potassium phosphate monobasic). These buffered runoff waters thus had high phosphate and high conductivity values. A second set of tests was also conducted using the same eight gutter and pipe materials which were immersed in unbuffered waters collected from Mobile Bay (saline) and the Black Warrior River at Tuscaloosa, Alabama. These experiments were performed to investigate the metal releases under natural $\mathrm{pH}$ conditions with varying salinity values associated with natural brackish bay water and river water. Water samples from leaching containers were periodically analyzed for a wide range of metallic and nutrient constituents and toxicity.

Some of these materials were found to release large amounts of zinc, copper and lead during the tests, with galvanized steel materials being the most significant source of lead and zinc, and copper materials being the greatest source of copper (as expected). Zinc, copper and lead releases were detected during both short and long exposure times under low and high $\mathrm{pH}$ conditions, and low and high salinity conditions.

Statistical analyses were performed to determine the effect of time, $\mathrm{pH}$, salinity and type of material on the release of the metals. Model fitting was performed on the time series plots to predict the release rate of metals as a function of exposure time and surface area.

\subsection{Introduction}

The dissolution of roof and pipe material is influenced by rainwater $\mathrm{pH}$ (AlMalack et al, 2001; Lasheen et al., 2008). Calcareous materials from cement roofs and concrete pipes and metal ions from metal and plastic materials can 
be dissolved by acidic rainwater (Degremont, 1979; Horvath, 2011). These processes result in weathering and deterioration of the roofing and piping materials. Material deterioration is dependent on such parameters as the time of contact with water and its chemical composition. Metal ions leaching from roofing materials are often in the most bioavailable forms, and consequently roof stormwater runoff can be a substantial source of stormwater toxicity.

Zinc, copper, aluminum and other heavy metals are commonly utilized in the construction of outdoor structures. Oxidation of metals results in significant metal releases to the environment. Shreir (1976) presents a detailed description of these processes. When zinc corrosion products are dissolved by rain and dew, zinc ions are leached from the corroded surfaces (Veleva et al., 2010). In one example in southeastern Mexico, $63 \%$ of roofs and walls are constructed using galvanized metals, which are subjected to corrosion (Veleva et al., 2010). The annual stormwater runoff from zinc roofs in Paris, France released approximately $34 \mathrm{t}$ to $64 \mathrm{t}$ zinc, which amounts to about half the total produced by stormwater runoff from the entire city (Gromaire et al., 2002).

\subsection{Materials and Methods}

Two series of laboratory tests of long term leaching were conducted using eight new gutter and pipe materials including those that are also used in tank construction. The first series of experiments was conducted to investigate the heavy metal releases under controlled $\mathrm{pH}$ conditions. Pipe and gutter materials were immersed for a 3 month period into locally collected roof runoff and parking lot runoff that were adjusted to $\mathrm{pH} 5$ and $\mathrm{pH} 8$, using buffer chemicals added to the runoff water (disodium phosphate dehydrate and potassium phosphate monobasic). These buffered runoff waters thus had high phosphate (2 $065 \mathrm{mg} / \mathrm{L}$ as $\mathrm{P}$ ) and high conductivity values $(>10 \mathrm{mS} / \mathrm{cm})$ that can affect the metal speciation during the tests. During this first test, the effects of $\mathrm{pH}$, time, and material type on contaminants leaching out of the drainage system materials were investigated. During the second testing series, the same eight pipe and gutter materials were immersed into unbuffered waters from Mobile Bay (saline) and the Black Warrior River in Alabama. These experiments were performed to examine the effects of salinity on the metal releases under natural $\mathrm{pH}$ conditions. Saline water was used to study the effect of salinity and chloride ions on metal releases, such as when pipe materials are exposed to snowmelt containing salt in stormwater runoff during spring months and for pipe crossings or outfall structures in brackish or saline waters.

The gutter materials used in the experiments included copper, aluminum, vinyl and galvanized steel, while the pipe materials were concrete, PVC (polyvinyl chloride), HDPE (high density polyethylene) and galvanized 
corrugated steel. All of the pipe and gutter materials were acquired from local building material stores in Tuscaloosa, Alabama. Galvanized steel, aluminum, PVC, HDPE and concrete materials are also often used in water tank construction. The pipe and gutter sections examined for the two $\mathrm{pH}$ tests were nearly identical. The test sections used in the natural water tests with varying salinity were also identical. All the pipe and gutter test segments were new and were $30.5 \mathrm{~cm}$ long, with the exception of the concrete pipes, which were $15.3 \mathrm{~cm}$ long (a smaller portion of the new concrete pipe was used during the second test series). The diameters for concrete, PVC, HDPE and galvanized steel pipe sections were $41.2 \mathrm{~cm}, 15.7 \mathrm{~cm}, 17.5 \mathrm{~cm}$ and $16.4 \mathrm{~cm}$ respectively. The diameters of galvanized steel gutter specimens were $15.2 \mathrm{~cm}$. The cross sectional dimensions of vinyl, aluminum and copper gutter segments were $5 \mathrm{~m} \times 8 \mathrm{~cm}, 8.4 \mathrm{~cm} \times 5.6 \mathrm{~cm}$ and $10.6 \mathrm{~cm} \times 7.2 \mathrm{~cm}$ respectively. The PVC, HDPE and galvanized steel pipes weighed approximately $1096 \mathrm{~g}, 409 \mathrm{~g}$ and $8000 \mathrm{~g}$ respectively. The approximate weights of the vinyl, aluminum, galvanized steel and copper pipes were $100 \mathrm{~g}, 79 \mathrm{~g}, 704 \mathrm{~g}$ and $503 \mathrm{~g}$ respectively. The weight of the concrete segments used in the first testing series was approximately $22400 \mathrm{~g}$ each; in the second testing series, the concrete pipe sections used weighed approximately $4400 \mathrm{~g}$.

In the course of the first testing series with buffered $\mathrm{pH}$ waters, each section of pipe and gutter material was submerged into $16 \mathrm{~L}$ plastic buckets, or $80 \mathrm{~L}$ containers for the concrete specimens, which contained the buffered roof runoff and parking lot runoff water that was adjusted to $\mathrm{pH}$ values of 5 and 8. Roof runoff collected from roof downspouts was used in the gutter material experiments and stormwater from parking areas before drain inlet was utilized in pipe material tests. During the first series of experiments the water from the containers was sampled and analyzed at times $0 \mathrm{~h}$ (water with adjusted $\mathrm{pH}$ but without specimens), $0.5 \mathrm{~h}, 1 \mathrm{~h}, 27 \mathrm{~h}, 1$ month, 2 month and 3 month for total concentrations of cadmium, chromium, lead, copper and zinc. Total aluminum and iron and filterable concentrations of lead, copper, zinc and aluminum were also analyzed after 3 month exposure. Samples were also screened using Microtox toxicity and analyzed for nutrient constituents (ammonia nitrogen, total nitrogen, and nitrate) and chemical oxygen demand (COD).

During the second series of tests, $14 \mathrm{~L}$ leaching containers with unmodified bay and river waters were sampled at times $0 \mathrm{~h}$ (natural bay and river waters without pipes), $1 \mathrm{~h}, 27 \mathrm{~h}, 1$ week, 1 month, 2 month and 3 month for total concentrations of lead, copper and zinc, and also screened for toxicity. Concentrations in $\mathrm{mg} / \mathrm{L}$ were converted to $\mathrm{mg}$ of constituent per surface area of a pipe or gutter in order to account for different area surfaces of the pipes and water volumes. 
Total iron and aluminum and filterable concentrations of iron were determined in the containers after 3 month exposure. Throughout the first and second testing series, $\mathrm{pH}$, conductivity and $\mathrm{Eh}$ (the half-cell potential relative to the standard hydrogen electrode; see Langmuir, 1997, and Garrels and Christ, 1990, for a complete definition and descriptions of how it is used in water chemistry modeling) were also measured, along with alkalinity, total and calcium hardness, chloride and sulfate.

Metal concentration analyses and quality control were performed by a commercial lab (Stillbrook Environmental Lab, in Fairfield, Alabama) using inductively coupled plasma mass spectroscopy. Detection limits for zinc, copper and lead concentrations were $20 \mu \mathrm{g} / \mathrm{L}, 20 \mu \mathrm{g} / \mathrm{L}$ and $5 \mu \mathrm{g} / \mathrm{L}$ respectively. The detection limits for cadmium and chromium were $5 \mu \mathrm{g} / \mathrm{L}$ and $20 \mu \mathrm{g} / \mathrm{L}$ respectively, and for aluminum and iron $100 \mu \mathrm{g} / \mathrm{L}$ and $20 \mu \mathrm{g} / \mathrm{L}$ respectively.

The lab ware used for sample collection and storage is made of polyethylene and was soaked in $10 \%$ nitric acid for at least $24 \mathrm{~h}$ before use and rinsed off with $18 \mathrm{~m} \Omega$ water to avoid heavy metal contamination. High density polyethylene containers were used for sample storage. Leaching buckets were washed using warm tap water and laboratory phosphate-free detergent, rinsed with tap water, washed with $10 \%$ nitric acid, then distilled water, followed by $18 \mathrm{~m} \Omega$ water. Polyethylene bottles were washed using warm tap water and laboratory phosphate-free detergent, rinsed with tap water, then deionized water, soaked in a $10 \%$ solution of reagent grade nitric acid for at least $24 \mathrm{~h}$ before use, and rinsed with laboratory grade $18 \mathrm{~m} \Omega$ water. The glassware used for sample collection was also cleaned with phosphate-free detergent, rinsed with tap water, deionized water, and soaked in a $10 \%$ nitric acid bath at least overnight and rinsed with $18 \mathrm{~m} \Omega$ water before use. Glassware used for toxicity analysis also was rinsed with sampled water. $18 \mathrm{~m} \Omega$ water was also used for method blanks. Water samples were placed in sample refrigerators set at $4^{\circ} \mathrm{C}$ until they were analyzed. Toxicity analyses were conducted in duplicate for each water sample. Standards and methods blanks were run together with the samples to confirm the instrument performance.

For the first series of tests, the data for $0.5 \mathrm{~h}, 1 \mathrm{~h}$ and $27 \mathrm{~h}$ were defined as short exposure periods, and for 1 month, 2 month and 3 month as long term exposure periods, based on results of statistical grouping analyses described later. For the second series of the experiments, the data for $1 \mathrm{~h}, 27 \mathrm{~h}$ and 1 week were defined as short exposure periods, and for 1 month, 2 month and 3 month as long term exposure periods.

For the graphical plots, half of the detection limit values were substituted for metal releases that were below the detection limit values, while non-detected values were not used in the statistical evaluations. In the graph legends, $P$ stands for pipe, $G$ stands for gutter. 


\subsection{Results and Discussions}

The tests showed that pipe and gutter materials can release substantial amounts of metals and can be a significant source of toxicity. The highest lead and zinc concentrations were observed for galvanized steel samples under buffered and natural $\mathrm{pH}$ conditions during both short and long exposure. The greatest copper release was observed from copper materials. Cadmium and chromium were not detected in any of the containers with controlled $\mathrm{pH}$ values.

\subsubsection{Copper Releases Under Controlled pH Conditions}

Copper materials were the greatest source of copper under controlled $\mathrm{pH}$ conditions. During short term exposure times, copper was released only in the copper gutter samples under both low and high $\mathrm{pH}$ values. Copper released from most of the other materials was detected after 1 month or 2 month exposure.

After 1 day exposure, copper concentrations in copper samples were $\sim 7 \mathrm{mg} / \mathrm{L}\left(480 \mathrm{mg} / \mathrm{m}^{2}\right)$ under $\mathrm{pH} 5$ conditions (exceeding the mean acute toxicity value for certain freshwater animals; USEPA, 2007) and $<1 \mathrm{mg} / \mathrm{L}$ $\left(21 \mathrm{mg} / \mathrm{m}^{2}\right)$ under $\mathrm{pH} 8$ conditions. Greater and faster releases occurred at lower $\mathrm{pH}$ conditions. Copper concentrations $>5 \mathrm{mg} / \mathrm{L}\left(320 \mathrm{mg} / \mathrm{m}^{2}\right)$ were detected in the copper gutter samples under $\mathrm{pH} 5$ conditions after long term exposure, compared to $2 \mathrm{mg} / \mathrm{L}\left(135 \mathrm{mg} / \mathrm{m}^{2}\right)$ values under the $\mathrm{pH} 8$ conditions. The greatest copper releases $\left(>6 \mathrm{mg} / \mathrm{L}, 480 \mathrm{mg} / \mathrm{m}^{2}\right)$ were detected from copper materials after $27 \mathrm{~h}$ exposure before they started to level off. Some of the plastic, aluminum and galvanized steel materials also released copper, but the concentrations were much lower. After the copper materials, PVC pipe samples had the highest copper releases of $\sim 5 \mathrm{mg} / \mathrm{m}^{2}$ after long exposure periods. Copper releases were detected in galvanized steel gutter and pipe samples under $\mathrm{pH} 8$ conditions. However, under $\mathrm{pH} 5$ conditions, the copper release was detected only at 1 month exposure for steel pipes. HDPE and galvanized steel materials had the lowest copper releases of $\leq 60 \mu \mathrm{g} / \mathrm{L}\left(1.24 \mathrm{mg} / \mathrm{m}^{2}\right)$ and $\leq 30 \mu \mathrm{g} / \mathrm{L}\left(1.36 \mathrm{mg} / \mathrm{m}^{2}\right)$ respectively. Copper releases were not detected in the concrete pipes samples at both $\mathrm{pH} 5$ and $\mathrm{pH} 8$ values.

Copper concentrations resulting from different materials during the buffered tests are shown in Figure 13.1 and Figure 13.2. The corresponding copper releases in $\mathrm{mg} / \mathrm{m}^{2}$ pipe surface area during the buffered tests are shown in Figures 13.3 and 13.4. The general shapes of the metal releases expressed in $\mathrm{mg} / \mathrm{L}$ are similar to the releases expressed in $\mathrm{mg} / \mathrm{m}^{2}$; the graphs of metal losses in $\mathrm{mg} / \mathrm{m}^{2}$ will be further used in this monograph, while a complete set of both types of figures are included in Ogburn (2013). 


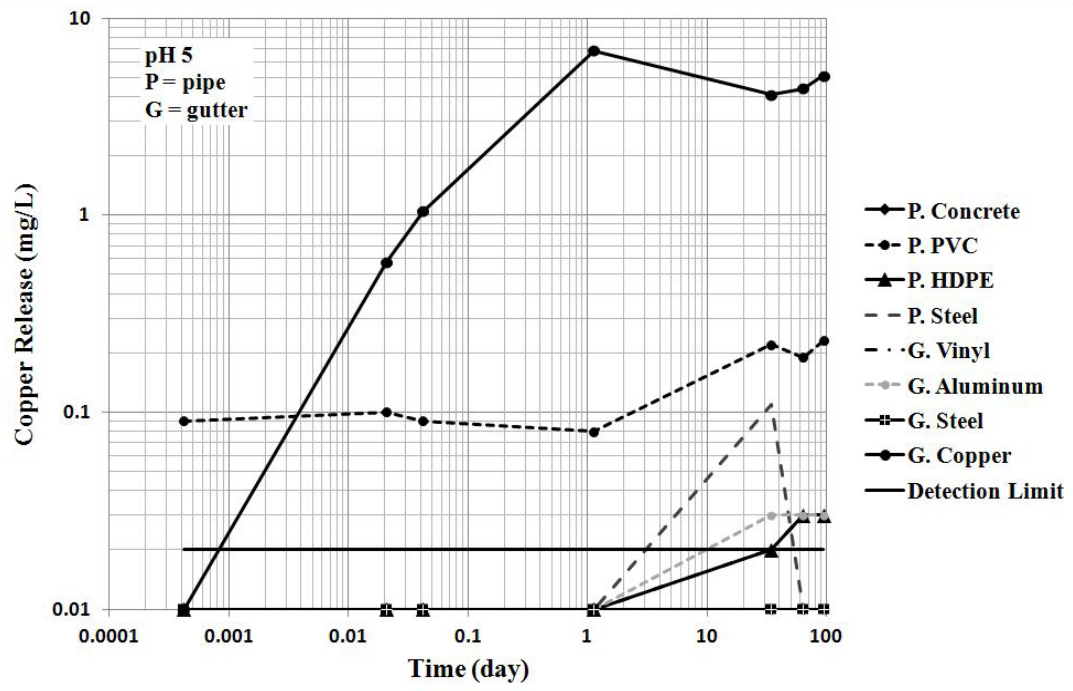

Figure 13.1 Total copper concentrations in containers with pH 5 water (Ogburn, 2013).

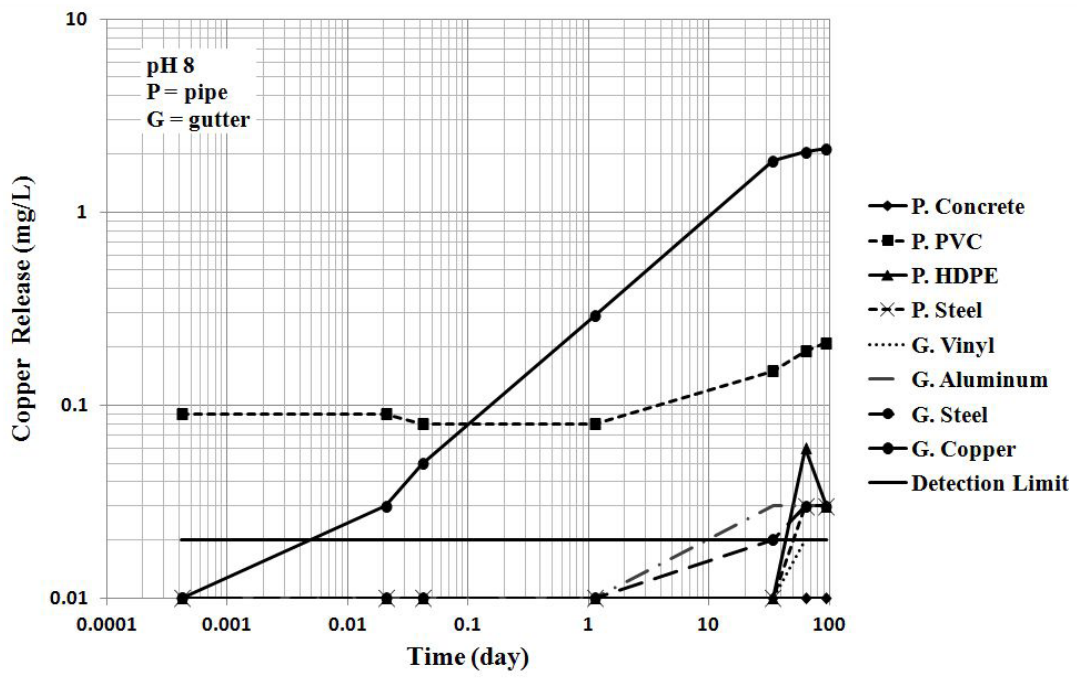

Figure 13.2 Total copper concentrations in containers with $\mathrm{pH} 8$ water (Ogburn, 2013). 


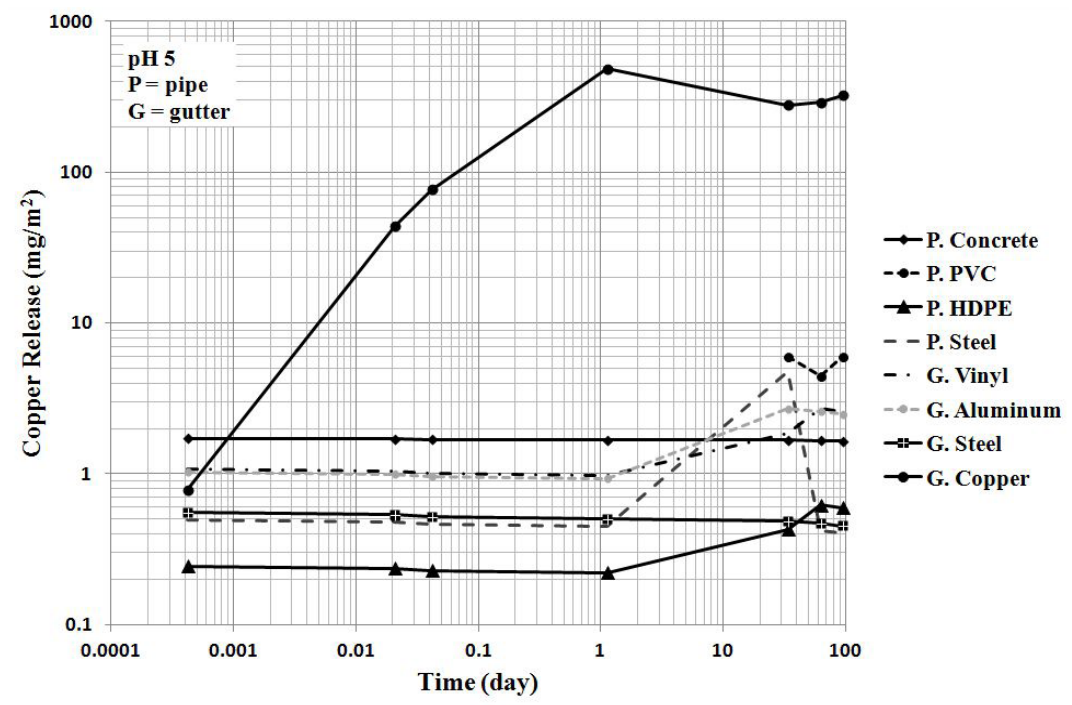

Figure 13.3 Total copper losses in containers with pH 5 water (Ogburn, 2013).

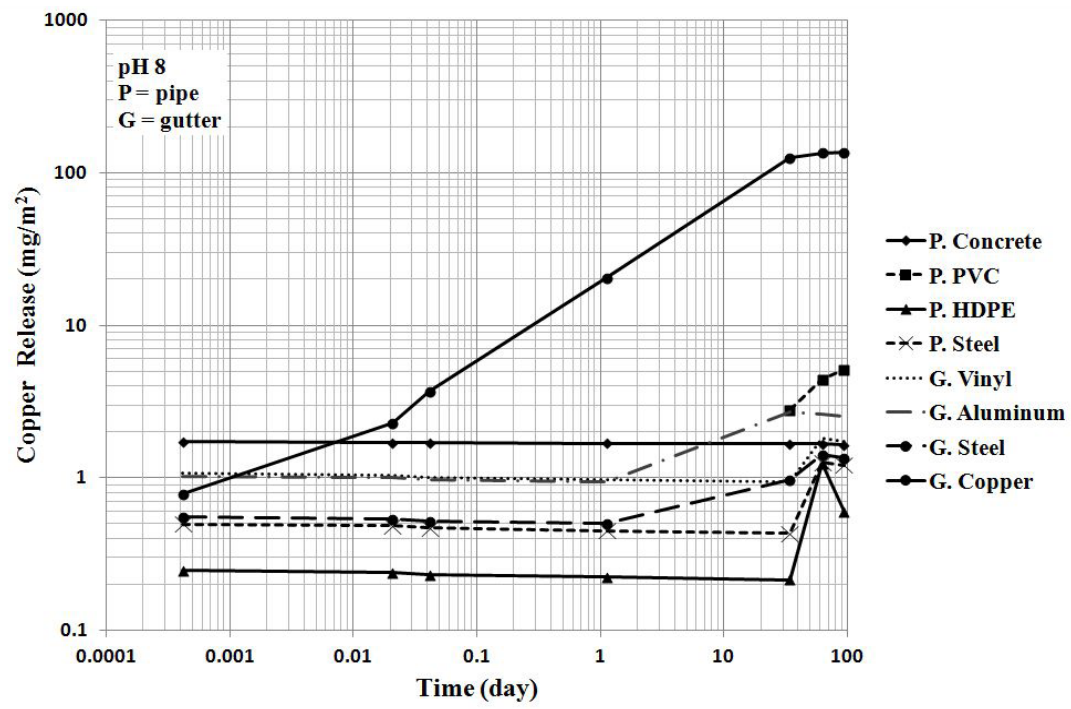

Figure 13.4 Total copper losses in containers with pH 8 water (Ogburn, 2013). 


\subsubsection{Copper Releases Under Natural pH Conditions}

Under natural $\mathrm{pH}$ conditions in the river and saline bay samples, copper releases were detected only from copper materials during both short and long exposure times.

For both bay and river waters, copper releases were observed after $1 \mathrm{~h}$ exposure. Copper materials immersed into bay water had slightly greater copper releases compared to containers with river water samples. After the first day of exposure, copper releases in bay water samples exceeded $2 \mathrm{mg} / \mathrm{L}$ $\left(140 \mathrm{mg} / \mathrm{m}^{2}\right)$.

After long term exposures ( 3 month), the greatest copper releases were noted from copper gutter sections immersed in bay water and reached $36 \mathrm{mg} / \mathrm{L}$ (2 $\left.200 \mathrm{mg} / \mathrm{m}^{2}\right)$, compared to $5.5 \mathrm{mg} / \mathrm{L}\left(340 \mathrm{mg} / \mathrm{m}^{2}\right)$ from copper gutter $\mathrm{sec}-$ tions immersed in river water, $5.1 \mathrm{mg} / \mathrm{L}\left(320 \mathrm{mg} / \mathrm{m}^{2}\right)$ from copper gutter sections under $\mathrm{pH} 5$ conditions, and $2.1 \mathrm{mg} / \mathrm{L}\left(135 \mathrm{mg} / \mathrm{m}^{2}\right)$ from copper sections under $\mathrm{pH} 8$ conditions. Copper releases were greater under $\mathrm{pH} 5$ conditions compared to $\mathrm{pH} 8$ conditions and could be explained by the more acidic environment. Higher copper releases in bay water compared to river water are attributed to the more aggressive environment due to the high chloride content (3 $350 \mathrm{mg} / \mathrm{L}$ ).

Copper releases in $\mathrm{mg} / \mathrm{m}^{2}$ pipe surface area from various materials during the unbuffered tests are shown in Figure 13.5 and Figure 13.6.

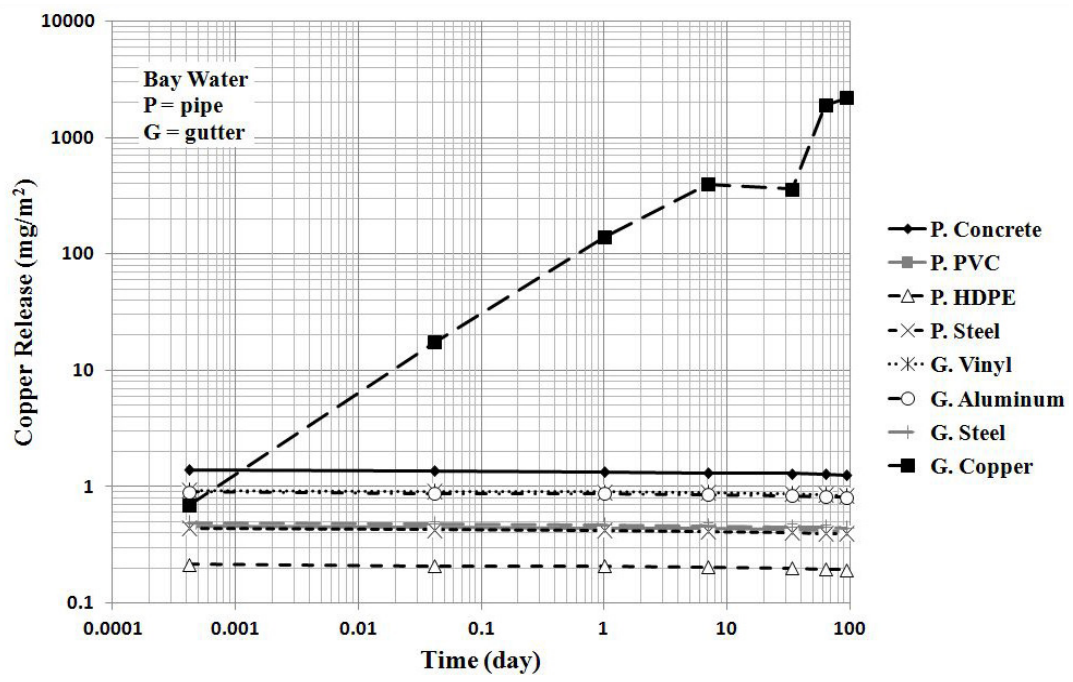

Figure 13.5 Total copper losses in containers with bay water (Ogburn, 2013). 


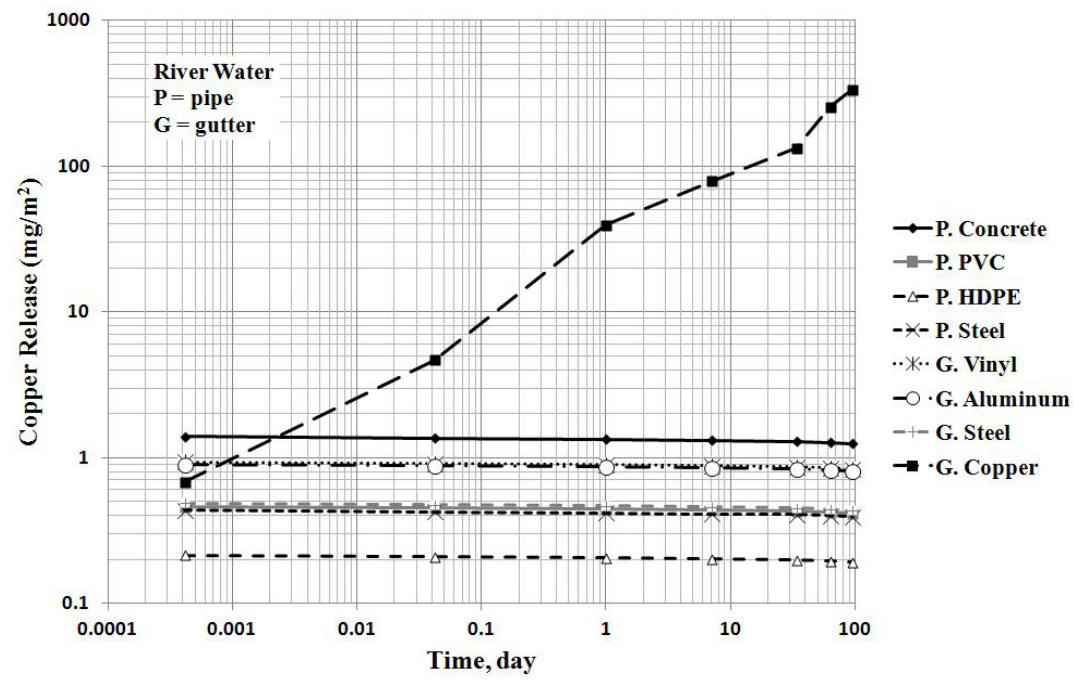

Figure 13.6 Total copper losses in containers with river water (Ogburn, 2013).

\subsubsection{Zinc Releases Under Controlled pH Conditions}

Figures 13.7 and Figure 13.8 show the zinc releases in $\mathrm{mg} / \mathrm{m}^{2}$ of pipe surface area resulting from different gutter and pipe materials during the buffered experiments.

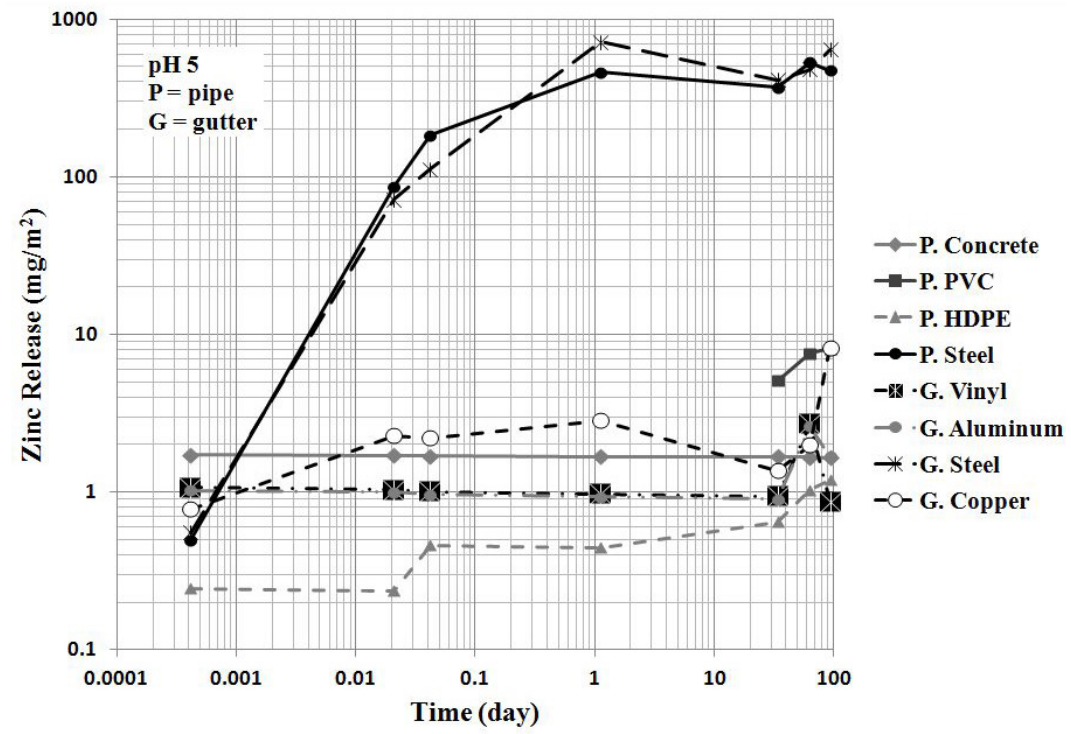

Figure 13.7 Total zinc losses in containers with pH 5 water (Ogburn, 2013). 


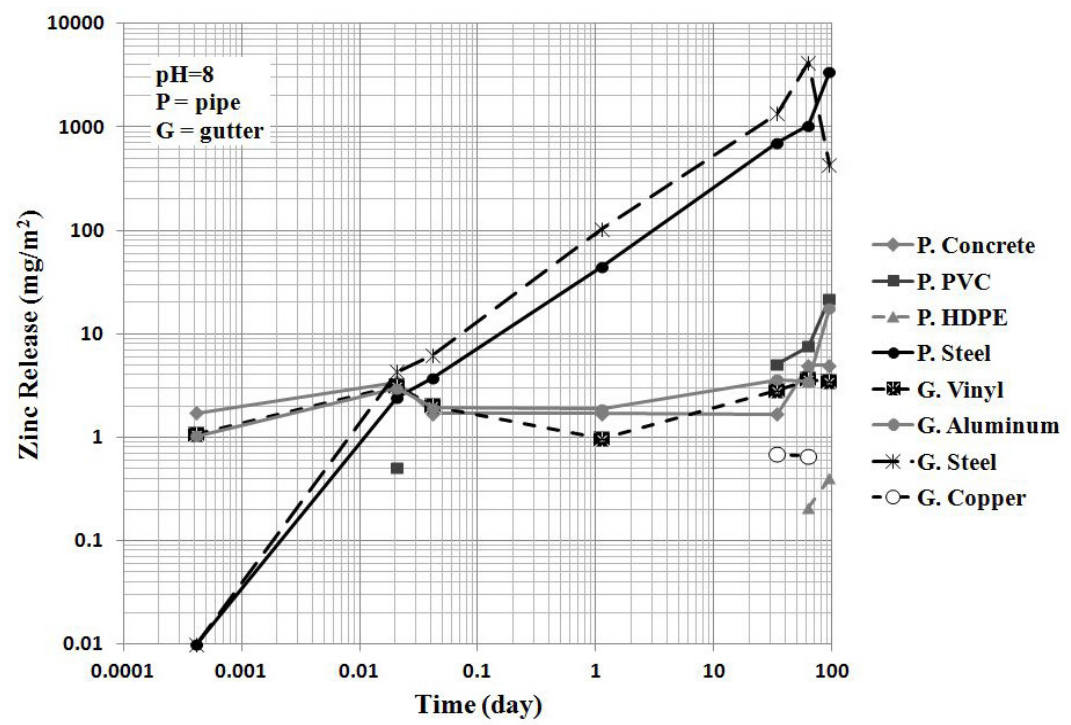

Figure 13.8 Total zinc losses in containers with $\mathrm{pH} 8$ water (Ogburn, 2013).

During short term exposures, zinc was released from the galvanized steel pipe and gutter at both low and high pHs, as well as from the copper and HDPE gutter samples at $\mathrm{pH}$, and from vinyl and aluminum gutters at $\mathrm{pH}$ 8. For other materials, zinc releases were noted after 1 month or 2 month exposure. After $1 \mathrm{~d}$ exposure, the galvanized steel pipes and gutters had very high levels of zinc concentrations ( $1 \mathrm{mg} / \mathrm{L}$ to $>14 \mathrm{mg} / \mathrm{L} ; 45 \mathrm{mg} / \mathrm{m}^{2}$ to $720 \mathrm{mg}$ / $\mathrm{m}^{2}$ ), with greater and faster releases observed under the lower $\mathrm{pH}$ conditions. These concentrations exceeded the aquatic life freshwater criteria of $120 \mu \mathrm{g} / \mathrm{L}$ established by the U.S. Environmental Protection Agency (USEPA) by 8 to 116 times. Zinc releases were the highest from galvanized steel materials.

During long term exposures (after 1 month), zinc concentrations in the samples with galvanized metals under $\mathrm{pH} 8$ conditions were $>90 \mathrm{mg} / \mathrm{L}$ (4 $\left.200 \mathrm{mg} / \mathrm{m}^{2}\right)$, compared with $14 \mathrm{mg} / \mathrm{L}\left(640 \mathrm{mg} / \mathrm{m}^{2}\right)$ values under the $\mathrm{pH}$ 5 conditions. Higher zinc losses at $\mathrm{pH} 8$ compared to $\mathrm{pH} 5$ can be attributed to zinc being an amphoteric species which dissolves well in acidic environments (with the formation of salts). It also dissolves well in basic environments (with the formation of divalent zincate anion (i.e. $\mathrm{CaZnO}_{2}$ ) or complex tetrahedral zincate ion (i.e. $\left.\mathrm{Na}_{2}\left[\mathrm{Zn}(\mathrm{OH})_{4}\right]\right)$ ) (Klinskiy and Skopinzev, 2001). Typically, zinc releases were greater in galvanized steel gutter samples compared to samples with galvanized pipes. The second highest sources of zinc were the copper gutters; greater releases occurred under $\mathrm{pH} 5$ conditions $\left(>0.13 \mathrm{mg} / \mathrm{L}, 8 \mathrm{mg} / \mathrm{m}^{2}\right)$. Zinc was also released from plastic materials, but 
the resultant concentrations were much lower. The least sources of zinc were concrete $\left(<30 \mathrm{~g} / \mathrm{L} ; 5 \mathrm{mg} / \mathrm{m}^{2}\right)$ and plastic materials (for PVC pipes $\leq 680 \mu \mathrm{g} / \mathrm{L}$ $\left(22 \mathrm{mg} / \mathrm{m}^{2}\right)$, for HDPE pipes $\leq 60 \mu \mathrm{g} / \mathrm{L}\left(1 \mathrm{mg} / \mathrm{m}^{2}\right)$, and for vinyl gutters $\left.\leq 40 \mu \mathrm{g} / \mathrm{L}\left(3.47 \mathrm{mg} / \mathrm{m}^{2}\right)\right)$.

\subsubsection{Zinc Releases Under Natural pH Conditions}

Short term exposures $(\leq 1$ week) resulted in zinc releases from the galvanized steel pipe and gutter materials immersed in both bay and river water and from copper gutter materials immersed in bay water. Zinc losses from the other materials were noted after 1 month or 2 month exposure. As for controlled $\mathrm{pH}$ conditions, galvanized steel materials in the containers under natural $\mathrm{pH}$ conditions were the greatest sources of zinc releases. The samples with galvanized steel gutters and pipes had very high levels of zinc concentrations (5 $\mathrm{mg} / \mathrm{L}$ to $>8 \mathrm{mg} / \mathrm{L} ; 230 \mathrm{mg} / \mathrm{m}^{2}$ to $350 \mathrm{mg} / \mathrm{m}^{2}$ ) after $1 \mathrm{~d}$ exposure, with greater releases observed for samples immersed into bay water. These concentrations exceeded the aquatic freshwater toxicity criteria of $120 \mu \mathrm{g} / \mathrm{L}$ established by USEPA by more than 40 times. However, after $1 \mathrm{~d}$ exposure, these concentrations were lower than the zinc concentrations in containers at controlled $\mathrm{pH} 5$ conditions $\left(>14 \mathrm{mg} / \mathrm{L}, 720 \mathrm{mg} / \mathrm{m}^{2}\right)$ and greater than zinc releases in containers at controlled $\mathrm{pH} 8$ tests $\left(>2 \mathrm{mg} / \mathrm{L}, 100 \mathrm{mg} / \mathrm{m}^{2}\right)$.

For galvanized pipes, zinc concentrations in bay water samples were generally higher than samples in river water samples. After long term exposure approaching 3 month, galvanized steel pipe samples immersed into bay waters resulted in zinc concentrations $>70 \mathrm{mg} / \mathrm{L}\left(3070 \mathrm{mg} / \mathrm{m}^{2}\right)$. However, galvanized gutter materials indicated a different trend and after 1 week exposure, zinc releases from galvanized gutters immersed in containers with river water exceeded those in bay water. After long term exposures, zinc losses from galvanized gutters in river water reached $190 \mathrm{mg} / \mathrm{L}\left(8310 \mathrm{mg} / \mathrm{m}^{2}\right)$ compared to $40 \mathrm{mg} / \mathrm{L}\left(1610 \mathrm{mg} / \mathrm{m}^{2}\right)$ in bay water. The higher zinc releases from the galvanized gutter specimen immersed in river water compared to the bay water can be explained by the lower $\mathrm{pH}$ and higher fluoride concentration in the river water sample. The different trends in the zinc releases from pipes and gutters are explained by different material compositions.

The second highest sources of zinc releases were the copper materials, with higher concentrations observed in containers with river water samples $\left(0.48 \mathrm{mg} / \mathrm{L}, 30 \mathrm{mg} / \mathrm{m}^{2}\right)$ compared to bay samples. Plastic and aluminum materials had much lower zinc releases. Zinc was not detected in concrete pipe samples with either bay or river waters.

Due to the high chloride content of the bay water, the zinc releases from galvanized steel pipe tended to be greater in bay water samples compared to 
river water samples. Figure 13.9 and Figure 13.10 show zinc releases resulted from various gutter and pipe materials during the unbuffered experiments.

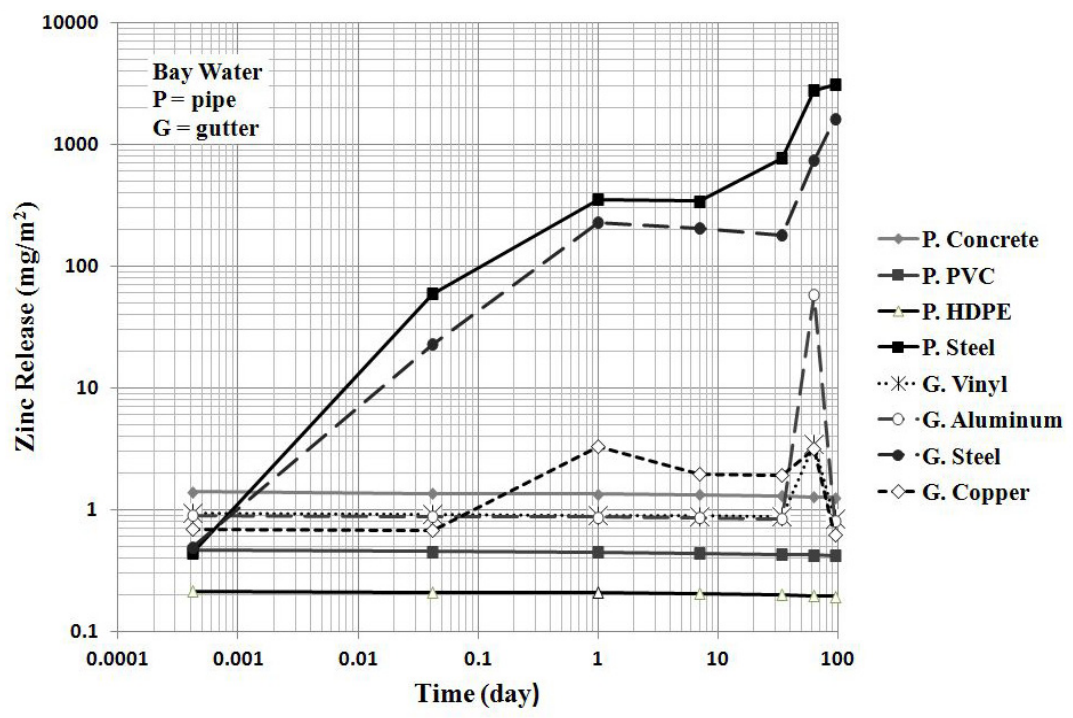

Figure 13.9 Total zinc losses in containers with bay water (Ogburn, 2013).

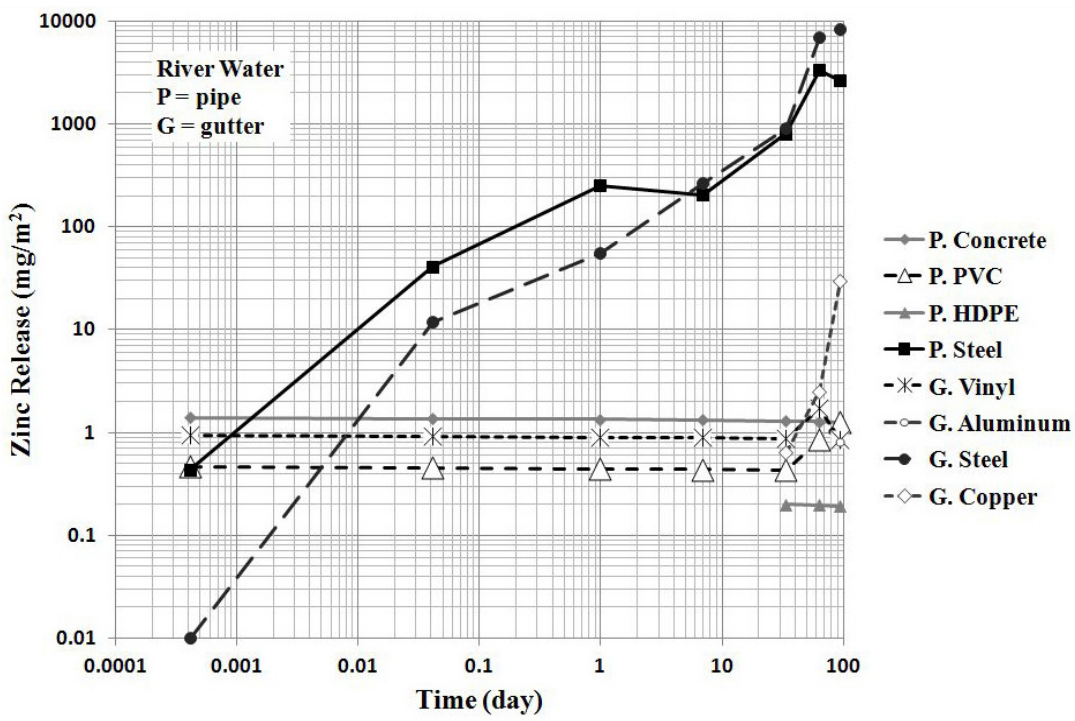

Figure 13.10 Total zinc losses in containers with river water (Ogburn, 2013). 


\subsubsection{Lead Releases Under Controlled pH Conditions}

Only galvanized materials were a source of lead releases during both short $(0.5 \mathrm{~h}$ to $27 \mathrm{~h}$ ) and long (1 month to 3 month) exposure for the samples tested.

During short exposure times, lead was not detected in any of the containers having galvanized steel, with the exception of the galvanized steel gutter sample under the $\mathrm{pH} 8$ conditions. This sample had a lead concentration of $8 \mu \mathrm{g} / \mathrm{L}\left(0.4 \mathrm{mg} / \mathrm{m}^{2}\right)$ at $27 \mathrm{~h}$ exposure and did not exceed the aquatic toxicity criteria of $65 \mu \mathrm{g} / \mathrm{L}$ established by USEPA. For the steel pipe and gutter specimens exposed at $\mathrm{pH} 5$, lead was detected after 1 month exposure, while the steel pipe sample exposed to $\mathrm{pH} 8$ conditions released lead after 2 month. Under both $\mathrm{pH}$ 5 and $\mathrm{pH} 8$ conditions, the release of lead was greater for steel pipe samples than for steel gutter samples probably due to different material compositions. For a given material, the releases of lead were greater at high $\mathrm{pH}$ conditions than low $\mathrm{pH}$ conditions which can be explained by lead amphoteric properties; lead can dissolve well in acidic environments with the formation of salts in which lead is a divalent cation; lead can also dissolve well in alkaline solutions and form complexes (i.e. $\mathrm{Na}_{2}\left[\mathrm{~Pb}(\mathrm{OH})_{4}\right]$, Klinskiy and Skopinzev, 2001). The greatest lead releases were observed for the galvanized steel pipe sample at $\mathrm{pH} 8$ which reached lead concentrations of $600 \mu \mathrm{g} / \mathrm{L}$ to $700 \mu \mathrm{g} / \mathrm{L}$ ( $25 \mathrm{mg} / \mathrm{m}^{2}$ to $30 \mathrm{mg} / \mathrm{m}^{2}$ ), followed by the galvanized steel pipe sample at $\mathrm{pH} 5$ with concentrations of $250 \mu \mathrm{g} / \mathrm{L}$ $\left(9.98 \mathrm{mg} / \mathrm{m}^{2}\right)$ after 3 month exposure. Samples with aluminum, copper and plastic materials did not contain any detectable lead concentrations. Lead releases resulting from different materials during the buffered tests are shown in Figure 13.11 and Figure 13.12.

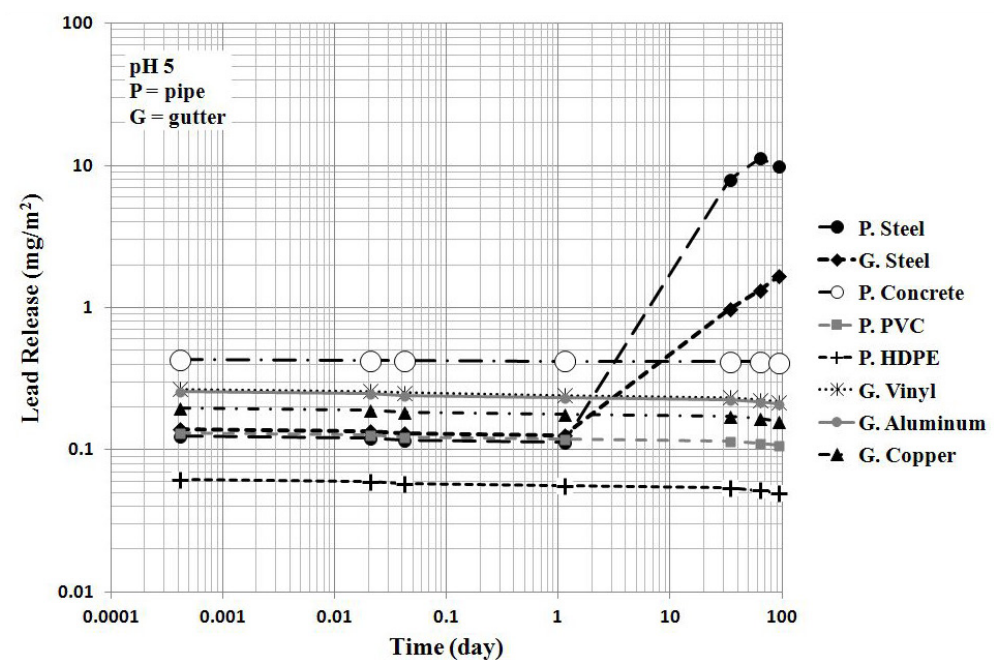

Figure 13.11 Total lead loss in containers with pH 5 water (Ogburn, 2013). 


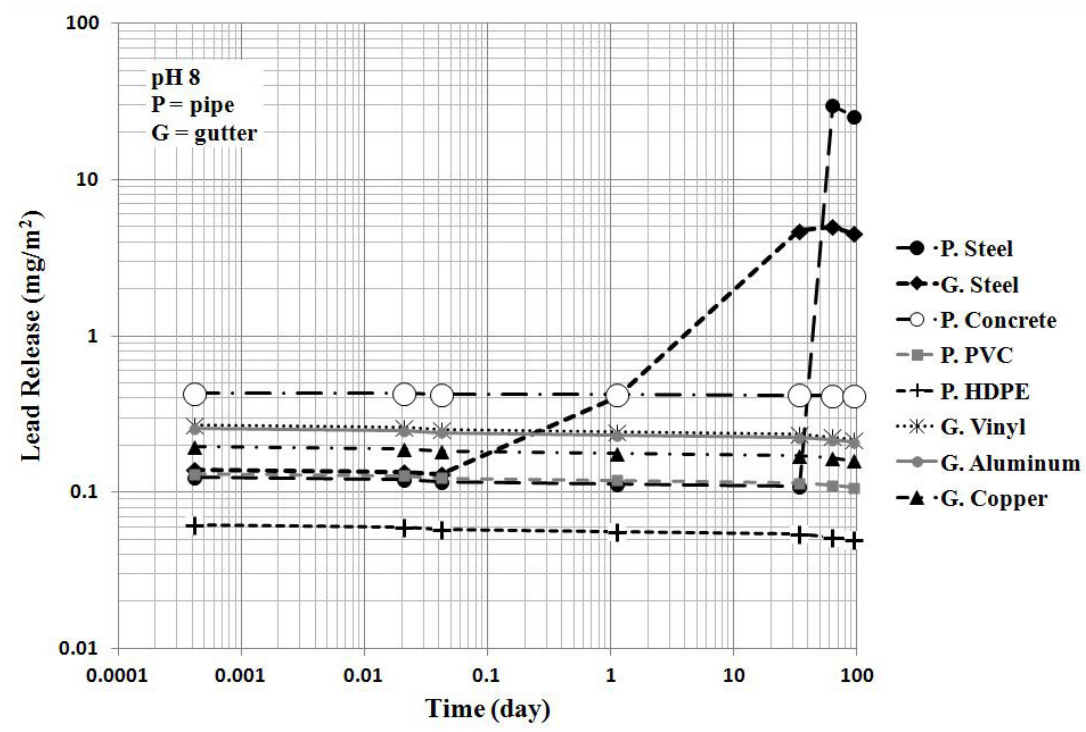

Figure 13.12 Total lead losses in containers with pH 8 water (Ogburn, 2013).

\subsubsection{Lead Releases Under Natural pH Conditions}

As during the controlled $\mathrm{pH}$ conditions, lead releases were detected only for galvanized steel materials during both short and long exposures for the bay and river waters under natural pHs. During short exposure (1h to 1 week), there were elevated lead concentrations noted from the galvanized steel materials immersed in bay and river waters. For example, a lead concentration of $0.012 \mathrm{mg} / \mathrm{L}\left(0.5 \mathrm{mg} / \mathrm{m}^{2}\right)$ was detected for the galvanized steel pipe section immersed into the bay water after $27 \mathrm{~h}$ exposure.

During long exposure (1 month to 3 month), periodic lead concentrations were detected only for galvanized steel materials immersed in containers having either bay or river waters. The greatest lead release of $0.058 \mathrm{mg} / \mathrm{L}$ $\left(2.54 \mathrm{mg} / \mathrm{m}^{2}\right)$ was observed after 3 month exposure of the steel gutter sample with river water. For galvanized steel materials, lead releases were greater in samples under controlled $\mathrm{pH}$ conditions compared to samples under natural $\mathrm{pH}$ conditions.

Figure 13.13 and Figure 13.14 show lead releases resulting from various pipe and gutter materials during the unbuffered experiments. 


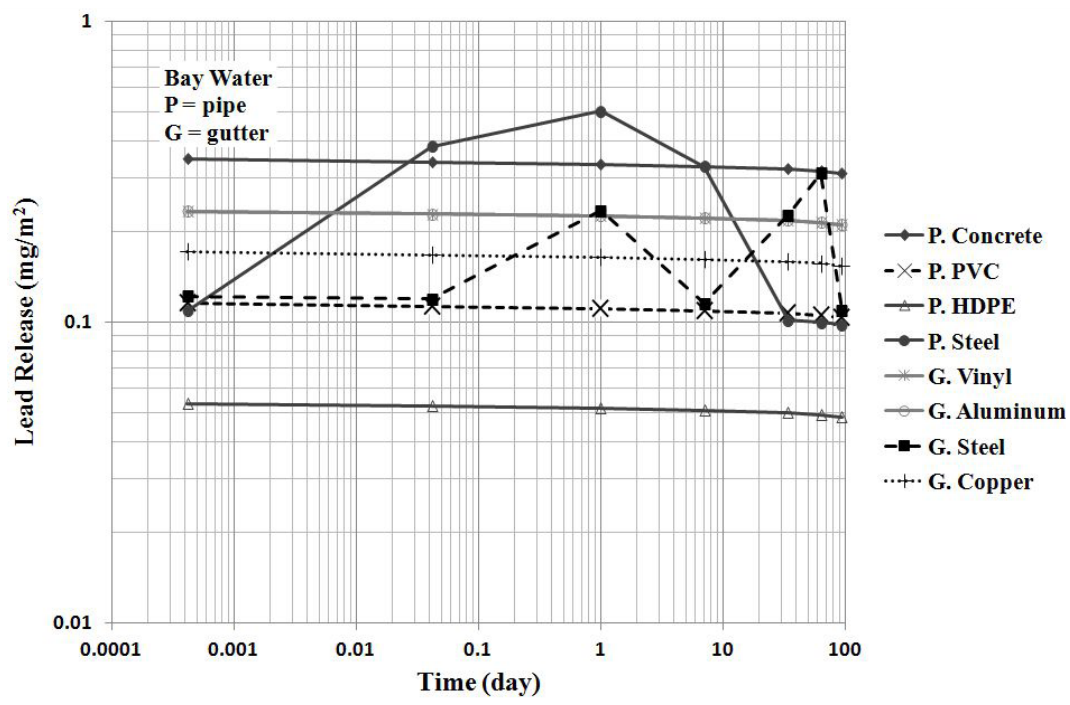

Figure 13.13 Total lead losses in containers with bay water (Ogburn, 2013).

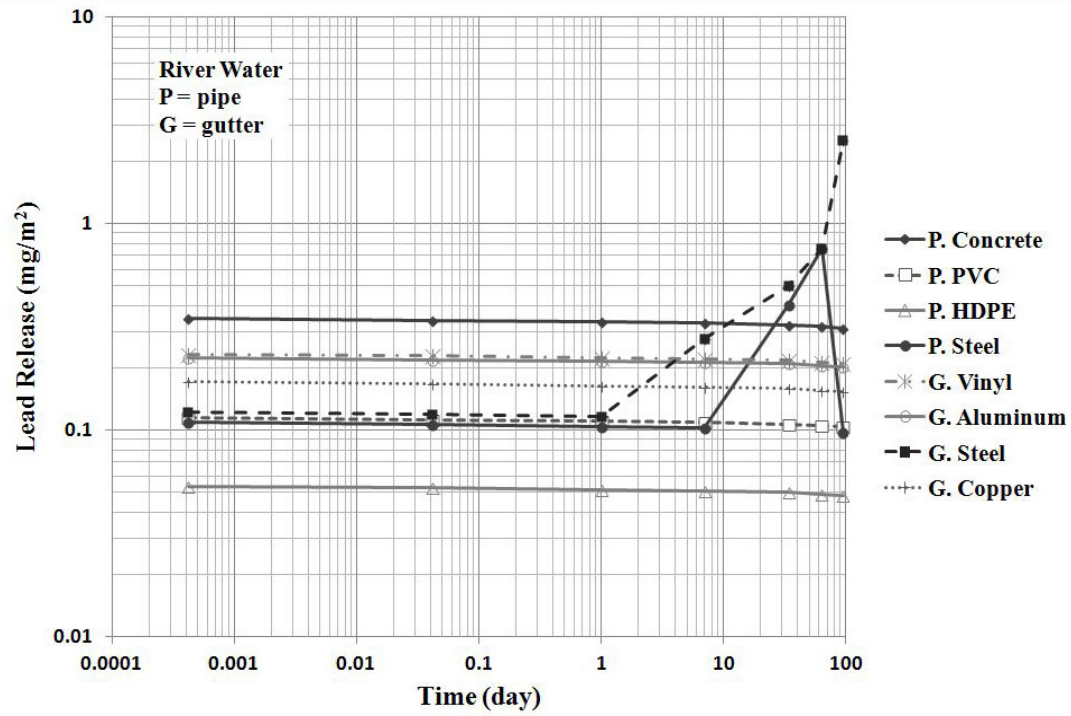

Figure 13.14 Total lead losses in containers with river water (Ogburn, 2013).

Table 13.1 shows zinc, lead and copper releases from the most significant sources after 3 month exposure. 
Table 13.1 Final zinc, lead, and copper releases.

\begin{tabular}{rccccc}
\hline Metal & Material & pH 5 & pH 8 & Bay & River \\
\hline $\mathrm{Zn}, \mathrm{mg} / \mathrm{m}^{2}$ & P. Galv. Steel & 470 & 3400 & 3100 & 2600 \\
$\mathrm{Zn}, \mathrm{mg} / \mathrm{m}^{2}$ & G. Galv. Steel & 640 & $4200^{*}$ & 1600 & 8300 \\
$\mathrm{~Pb}, \mathrm{mg} / \mathrm{m}^{2}$ & P. Galv. Steel & 10 & 25 & $\mathrm{ND}$ & $\mathrm{ND}$ \\
$\mathrm{Pb}, \mathrm{mg} / \mathrm{m}^{2}$ & G. Galv. Steel & 1.7 & 4.5 & $\mathrm{ND}$ & 2.5 \\
$\mathrm{Cu}, \mathrm{mg} / \mathrm{m}^{2}$ & G. Copper & 320 & 140 & 2200 & 340 \\
\hline
\end{tabular}

*After 2 month exposure

\subsubsection{Iron and Aluminum Releases Under Controlled and Natural $\mathrm{pH}$ Conditions}

Iron releases from galvanized steel materials exceeded those from other materials and were greater under $\mathrm{pH} 5$ conditions than under $\mathrm{pH} 8$ conditions. At $\mathrm{pH} 5$ the releases ranged between $6 \mathrm{mg} / \mathrm{L}$ and $22 \mathrm{mg} / \mathrm{L}\left(260 \mathrm{mg} / \mathrm{m}^{2}\right.$ and $\left.850 \mathrm{mg} / \mathrm{m}^{2}\right)$ and around $1 \mathrm{mg} / \mathrm{L}\left(<45 \mathrm{mg} / \mathrm{m}^{2}\right)$ at $\mathrm{pH} 8$. Iron releases from the galvanized steel specimens submerged into bay and river water were between $1 \mathrm{mg} / \mathrm{L}$ and $2 \mathrm{mg} / \mathrm{L}\left(<66.49 \mathrm{mg} / \mathrm{m}^{2}\right)$ and were similar to iron releases at $\mathrm{pH} 8$ values. Iron concentrations leached from concrete pipes in bay water $(>2 \mathrm{mg} / \mathrm{L}$; $\left.68.3 \mathrm{mg} / \mathrm{m}^{2}\right)$ were greater than those in river water $\left(<1 \mathrm{mg} / \mathrm{L} ; 25 \mathrm{mg} / \mathrm{m}^{2}\right)$. The highest concentrations of aluminum were detected in the containers having aluminum materials and were $\leq 1 \mathrm{mg} / \mathrm{L}\left(<80 \mathrm{mg} / \mathrm{m}^{2}\right)$ for all conditions and did not exceed the aquatic freshwater toxicity criteria for aluminium of $750 \mu \mathrm{g} / \mathrm{L}$ established by USEPA.

\subsubsection{Statistical Analysis}

Statistical analyses were conducted to determine the behavior of pollutant leaching from the gutter and piping materials depending on exposure time and $\mathrm{pH}$ (during the first test series) and on exposure time and salinity (during the second series of tests). The heavy metal releases per unit area were compared for the various gutter and pipe materials.

Kruskal-Wallis tests were performed on the metals data (zinc, copper and lead) for each of the test series for 1 month, 2 month and 3 month exposure to determine if there was a statistically significant difference between these data points. The tests showed that the data for 1 month, 2 month and 3 month exposure can be combined as replicates of long term exposure times. Also, Kruskal-Wallis tests were conducted on the metal data after $0.5 \mathrm{~h}, 1 \mathrm{~h}$ and $27 \mathrm{~h}$ exposure during the first test series, and on the metal data after $1 \mathrm{~h}$, $27 \mathrm{~h}$ and 1 week exposure during the second series of the experiments. These tests also showed that these data can be combined as replicates of short term exposure times at 0.05 significance level. 
Mann-Whitney tests were performed next to determine whether there were any statistically significant differences between the groups. The MannWhitney test was used because some of the data did not meet the assumptions of normality and equal variance (log transformations of the data also did not result in normally distributed values). As an example, the Mann-Whitney Test P-values for zinc releases from different pipe and gutter materials under controlled $\mathrm{pH}$ conditions are shown in the Table 13.3. The results showed that there was a difference (at the 0.05 significance level) between the majority of the groups. The exception included the difference between HDPE groups and copper $\mathrm{pH} 8$ group.

Table 13.3 Mann-Whitney test P-values for zinc releases under controlled pH conditions (from Ogburn 2013).

\begin{tabular}{|c|c|c|c|c|c|c|c|c|c|c|c|c|c|c|}
\hline & రే & $\begin{array}{l}\dot{n} \\
\dot{0} \\
\dot{2}\end{array}$ & $\dot{u}$ & $\begin{array}{l}n \\
\text { 点 } \\
\text { 目 }\end{array}$ & $\begin{array}{l}\infty \\
\underline{1} \\
\hat{\mid}\end{array}$ & $\begin{array}{l}\dot{s} \\
\text { 떼 } \\
\text { |े }\end{array}$ & 窐 & $\begin{array}{l}\ddot{n} \\
\text { n. }\end{array}$ & 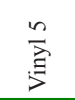 & 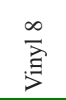 & $\frac{\Xi}{\text { 灵 }}$ & $\begin{array}{l}\dot{\omega} \\
\dot{\omega}\end{array}$ & 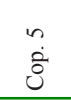 & $\begin{array}{l}\infty \\
\dot{0} \\
\dot{0}\end{array}$ \\
\hline Con & & $<0.001$ & $<0.001$ & $<0.001$ & $<0.001$ & $<0.001$ & $<0.001$ & $<0.001$ & 0.013 & 0.325 & 0.931 & $<0.001$ & 0.281 & $<0.001$ \\
\hline PVC S. & & & 0.002 & 0.015 & 0.18 & 0.18 & 0.015 & $<0.001$ & 0.002 & 0.002 & $<0.001$ & $<0.001$ & 0.002 & 0.065 \\
\hline PVC L. & & & & 0.002 & 0.002 & 0.002 & 0.002 & 0.028 & 0.003 & 0.003 & 0.004 & 0.017 & 0.041 & 0.002 \\
\hline HDPE 5 & & & & & 0.004 & 0.026 & 0.589 & $<0.001$ & 0.18 & 0.009 & 0.01 & $<0.001$ & 0.002 & 0.132 \\
\hline HDPE 8 & & & & & & 0.589 & 0.026 & $<0.001$ & 0.002 & 0.002 & $<0.001$ & $<0.001$ & 0.002 & 0.24 \\
\hline HDPE S & & & & & & & 0.132 & $<0.001$ & 0.002 & 0.002 & $<0.001$ & $<0.001$ & 0.002 & 0.394 \\
\hline HDPE L & & & & & & & & $<0.001$ & 0.18 & 0.009 & 0.01 & $<0.001$ & 0.002 & 0.24 \\
\hline P. St & & & & & & & & & 0.001 & 0.003 & $<0.001$ & 0.795 & 0.022 & $<0.001$ \\
\hline Vinyl 5 & & & & & & & & & & 0.026 & 0.174 & $<0.001$ & 0.026 & 0.002 \\
\hline Vinyl 8 & & & & & & & & & & & 0.281 & $<0.001$ & 0.699 & 0.002 \\
\hline Alum & & & & & & & & & & & & $<0.001$ & 0.482 & $<0.001$ \\
\hline G. St & & & & & & & & & & & & & 0.002 & $<0.001$ \\
\hline Cop. 5 & & & & & & & & & & & & & & 0.002 \\
\hline Cop. 8 & & & & & & & & & & & & & & \\
\hline
\end{tabular}

Con = concrete; $\mathrm{St}=$ galvanized steel; Alum = Aluminum; $\mathrm{Cop}=$ copper; $\mathrm{S}=$ short exposure time;

$\mathrm{L}=$ long exposure time; $5=\mathrm{pH} 5 ; 8=\mathrm{pH} 8 ; \mathrm{P}=$ pipe; $\mathrm{G}=$ gutter.

Group box plots were plotted on a log scale for each metal constituent to illustrate the variations and differences between each group. Figure 13.15 is a group box plot of copper releases from copper materials under $\mathrm{pH} 5 \mathrm{vs} \mathrm{pH} 8$ conditions. Low $\mathrm{pH}$ conditions and exposure time increased released copper. The 75th percentile of the box plot for copper releases under $\mathrm{pH} 5$ conditions during short time exposure is higher than that of copper releases under the same conditions during long exposure time and was an unusually high value. Figure 13.16 shows copper releases from copper materials in bay and river waters. The copper releases increased with the exposure time; greater concentrations were observed for the samples in the bay water possibly due to the higher content of the chloride ion which causes corrosion (Corvo, 2005; Gabriel and Moran, 1998). 


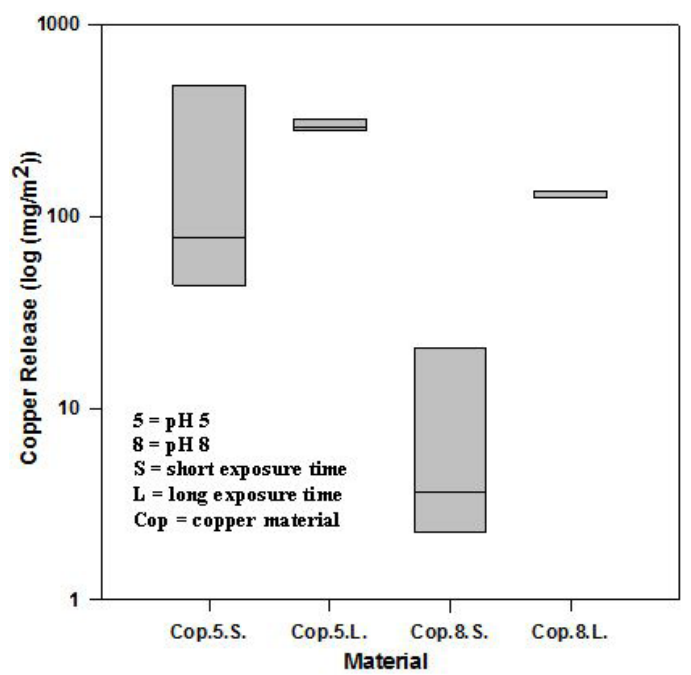

Figure 13.15 Group box plot for copper release in $\mathrm{mg} / \mathrm{m}^{2}$ for copper materials immersed in $\mathrm{pH} 5$ and $\mathrm{pH} 8$ waters (Ogburn, 2013).

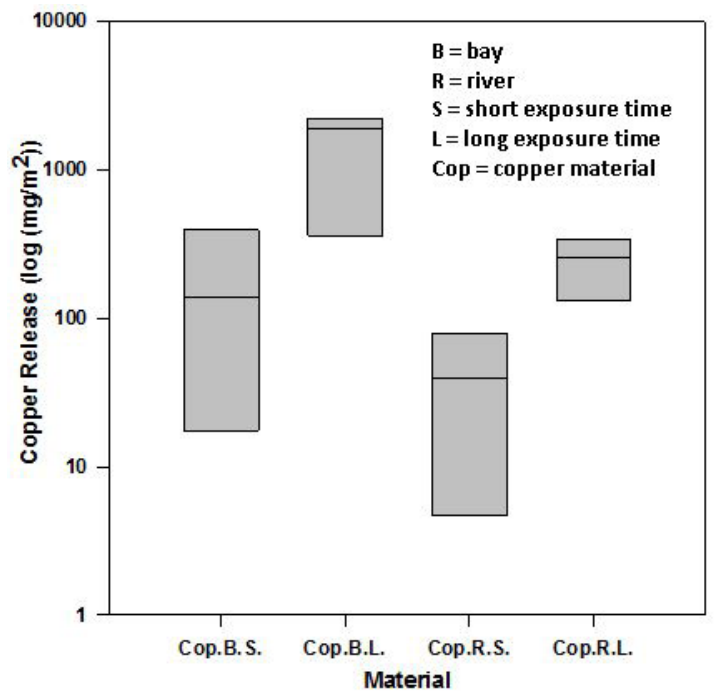

Figure 13.16 Group box plot for copper release in $\mathrm{mg} / \mathrm{m}^{2}$ for copper materials immersed in bay and river waters (Ogburn, 2013). 
Figure 13.17 shows zinc releases from various gutter and pipe materials under controlled $\mathrm{pH}$ conditions. Concrete, galvanized steel and aluminum material box plots represent all the data combined (short and long exposure times for both $\mathrm{pH} 5$ and $\mathrm{pH} 8$ conditions). Box plots for PVC and HDPE materials show the data during long term exposure, with both $\mathrm{pH} 5$ and $\mathrm{pH} 8$ combined. Box plots for vinyl and copper materials represent the data with short and long exposure times combined. Galvanized steel materials have significantly higher zinc releases compared to the rest of materials.

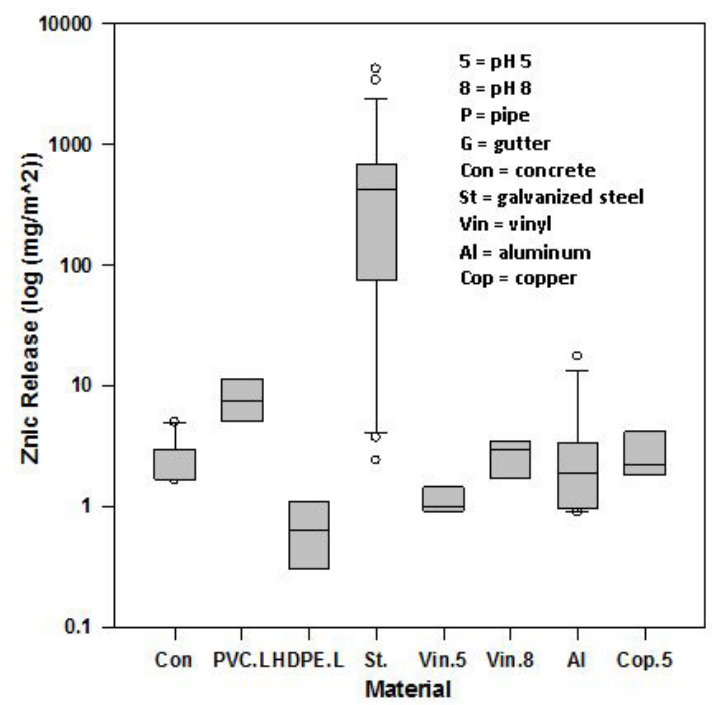

Figure 13.17 Group box plot for zinc release in $\mathrm{mg} / \mathrm{m}^{2}$ for different gutter and pipe materials immersed in $\mathrm{pH} 5$ and $\mathrm{pH} 8$ waters (Ogburn, 2013).

Figure 13.18 below shows zinc releases for the materials exposed to bay and river waters. The box plots for plastics represents all the data combined (for bay and river waters and for short and long exposure times). As the exposure time increased, the zinc releases also increased.

Figure 13.19 shows lead releases from galvanized steel materials under controlled $\mathrm{pH}$ conditions. Box plots for lead releases from galvanized steel pipes during short exposure times at $\mathrm{pH} 5$ and 8, as well as from galvanized steel gutters during short exposure times at $\mathrm{pH}$, were below detection limits and therefore were not plotted. As can be seen from the figure, longer exposure time increased lead releases. 


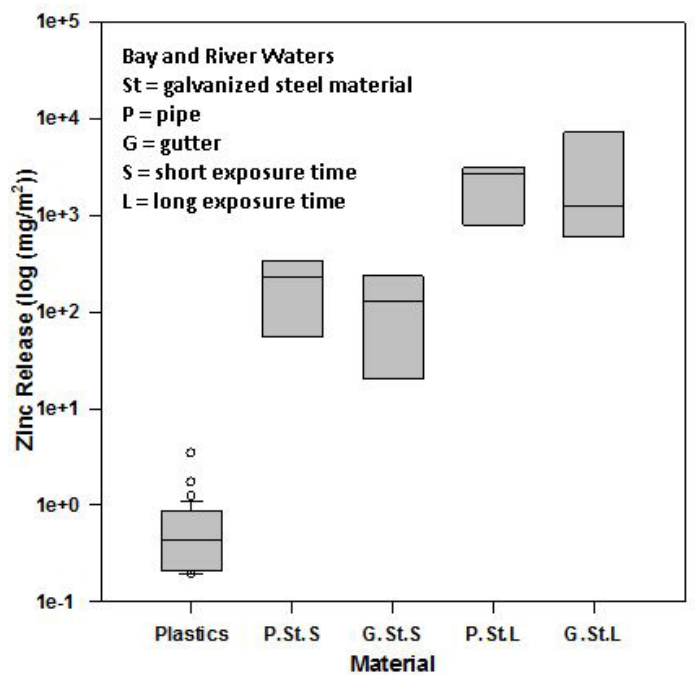

Figure 13.18 Group box plot for zinc release in $\mathrm{mg} / \mathrm{m}^{2}$ for various gutter and pipe materials immersed in bay and river waters (Ogburn, 2013).

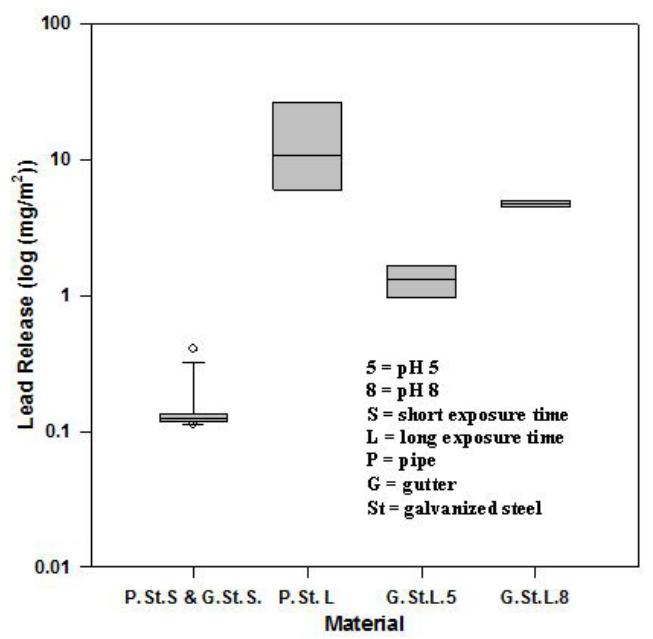

Figure 13.19 Group box plot for lead release in $\mathrm{mg} / \mathrm{m}^{2}$ for galvanized steel materials immersed in $\mathrm{pH} 5$ and $\mathrm{pH} 8$ waters (Ogburn, 2013).

Figure 13.20 shows lead releases from galvanized steel materials under natural $\mathrm{pH}$ conditions. Lead releases during both short and long exposure 
times and under both bay and river conditions do not differ significantly between the groups, with the group of lead releases from galvanized steel gutters immersed into river water during long exposure times being slightly higher than the rest of the groups.

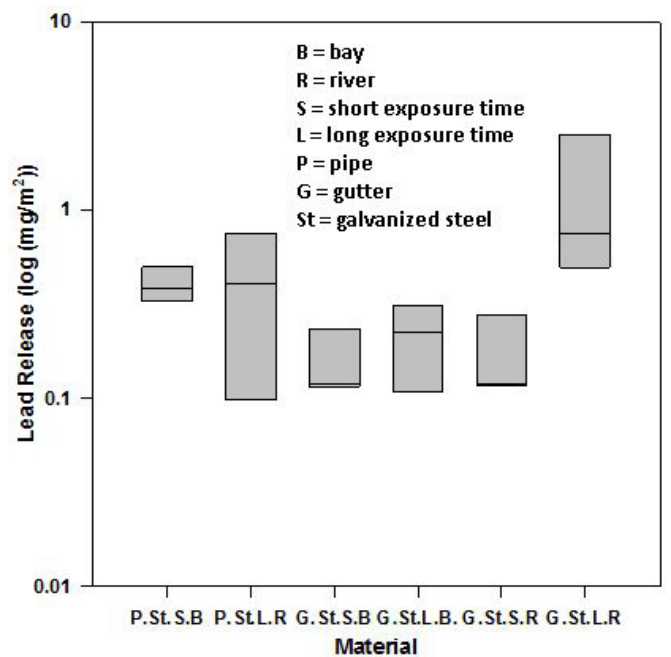

Figure 13.20 Group box plot for lead release in $\mathrm{mg} / \mathrm{m}^{2}$ for galvanized steel materials immersed in bay and river waters (Ogburn, 2013).

\subsubsection{Toxicity Under Controlled and Natural pH Conditions}

During the controlled $\mathrm{pH}$ tests, the highest toxicities were found for copper and aluminum material exposures; the samples from concrete containers were the least toxic. In containers with bay and river waters, copper materials had the highest toxicity values, followed by galvanized steel materials.

\subsubsection{Model Fitting}

Linear regression was conducted on time series plots of log metal releases per pipe surface area vs log time for different pipe and gutter materials under controlled and natural $\mathrm{pHs}$. The regression analyses results are shown in Table 13.4, Table 13.5 and Table 13.6. There were six time series data points for each plot. The majority of the scatterplots revealed that first order polynomials can be fitted to the log of metal releases vs log of time. 
Table 13.4 Regression analysis results for zinc, lead, and copper releases under controlled and natural $\mathrm{pH}$ conditions (Ogburn 2013).

\begin{tabular}{|c|c|c|c|c|c|c|c|}
\hline $\begin{array}{l}\text { Metal, Pipe, } \\
\text { Condition }\end{array}$ & $\begin{array}{l}\text { Data Correl., r, } \\
\text { (P-Value) }\end{array}$ & $\begin{array}{c}\text { Data Normality } \\
\text { AD statistic } \\
\text { (P-Value) }\end{array}$ & $\begin{array}{l}\text { Coeff. m } \\
\text { (P-Value) }\end{array}$ & $\begin{array}{l}\text { Coeff. b } \\
\text { (P-Value) }\end{array}$ & $\begin{array}{l}\text { Regress. } \\
\text { (P-Value) }\end{array}$ & $\begin{array}{c}R^{2} \text { adj., } \\
\%\end{array}$ & $\begin{array}{c}\text { Std Error } \\
\text { of the } \\
\text { Estimate, } \mathrm{S} \\
\end{array}$ \\
\hline Cu.G.Cop.B & $0.855(0.065)$ & $0.281(0.509)$ & $1.245(0.003)$ & $0.587(0.002)$ & 0.002 & 91.4 & 0.2288 \\
\hline Cu.G.Cop.R & $0.966(0.008)$ & $0.318(0.409)$ & $0.725(0.001)$ & $0.525(0.000)$ & 0.000 & 98.0 & 0.0950 \\
\hline $\begin{array}{l}\text { Cu.G.Cop. } 5 \\
\text { (Linear) }\end{array}$ & 0.4 & $0.507(0.118)$ & $1.916(0.000)$ & $0.202(0.053)$ & 0.053 & 56.0 & 0.2716 \\
\hline $\begin{array}{l}\text { Cu.G.Cop. } 5 \\
\text { (2 Segments) }\end{array}$ & 0.4 & $0.507(0.118)$ & - & - & 0.0123 & 97.95 & 0.0586 \\
\hline Cu.G.Cop. 8 & $0.887(0.045)$ & $0.534(0.098)$ & $0.552(0.000)$ & $0.499(0.000)$ & 0.000 & 99.2 & 0.0746 \\
\hline Zn.P.St.B & $0.838(0.076)$ & $0.277(0.516)$ & $1.736(0.001)$ & $0.477(0.004)$ & 0.004 & 87.7 & 0.2264 \\
\hline Zn.G.St.B & $0.592(0.293)$ & $0.304(0.446)$ & $1.435(0.006)$ & $0.438(0.017)$ & 0.017 & 74.5 & 0.3179 \\
\hline Zn.P.St.R & $0.800(0.104)$ & $0.227(0.678)$ & $1.528(0.003)$ & $0.535(0.006)$ & 0.006 & 85.1 & 0.282 \\
\hline Zn.G.St.R & $0.831(0.376)$ & $0.278(0.486)$ & - & $1.131(0.000)$ & 0.000 & 96.3 & 0.5819 \\
\hline Zn.P.St.5 & $0.766(0.131)$ & $0.526(0.104)$ & $2.181(0.000)$ & $0.165(0.025)$ & 0.025 & 69.4 & 0.1713 \\
\hline Zn.G.St.5 & $0.521(0.368)$ & $0.497(0.124)$ & $2.095(0.000)$ & $0.216(0.036)$ & 0.036 & 63.3 & 0.2541 \\
\hline Zn.P.St.8 & $0.920(0.027)$ & $0.340(0.355)$ & $0.569(0.004)$ & $0.812(0.000)$ & 0.000 & 98.7 & 0.1521 \\
\hline Zn.G.St.8 & $0.752(0.142)$ & $0.263(0.550)$ & $0.878(0.028$ & $0.717(0.003)$ & 0.003 & 88.7 & 0.4118 \\
\hline Pb.G.St.R & $0.939(0.018)$ & $0.239(0.631)$ & $-1.1566(0.010)$ & $0.3439(0.028)$ & 0.028 & 67.3 & 0.293538 \\
\hline Pb.P.St. 5 & $(>0.05)$ & $0.830(0.013)$ & $-1.029(0.020)$ & $0.598(0.007)$ & 0.007 & 82.8 & 0.4365 \\
\hline Pb.G.St. 8 & 0.807 (0.099) & $0.627(0.053)$ & $-0.852(0.001)$ & $0.472(0.000)$ & 0.000 & 96.1 & 0.1544 \\
\hline
\end{tabular}

Linear Regression equation: $\log \left(\right.$ Conc., $\left.\mathrm{mg} / \mathrm{m}^{2}\right)=\mathrm{m}+\mathrm{b} \log ($ Time, $\mathrm{hr})$

2 Segment Linear Regression for Cu.G.Cop.5: $\mathrm{t} 1=\min (\log$ Time $)$; $2=\max (\log$ Time $)$

Segment $1(\log$ Time $): \log \left(\right.$ Conc., $\left.\mathrm{mg} / \mathrm{m}^{2}\right)=(\mathrm{y} 1 \times(\mathrm{T} 1-\log$ Time $)+\mathrm{y} 2 \times(\log$ Time$-\mathrm{t} 1)) /(\mathrm{T} 1-\mathrm{t} 1)$

Segment $2(\log$ Time $): \log \left(\right.$ Conc., $\left.\mathrm{mg} / \mathrm{m}^{2}\right)=(\mathrm{y} 2 \times(\mathrm{t} 2-\log$ Time $)+\mathrm{y} 3 \times(\log$ Time $-\mathrm{T} 1)) /(\mathrm{t} 2-\mathrm{T} 1)$

$\mathrm{f}=\mathrm{if}(\log$ Time $\leq \mathrm{T} 1$, Segment $1(\log$ Time $)$, Segment2 $(\log$ Time $))$

Table 13.5 Examination of the residuals of the regression analysis for zinc, lead, and copper releases under controlled and natural $\mathrm{pH}$ conditions.

\begin{tabular}{lccc}
\hline \multicolumn{1}{c}{ Metal, Pipe, Condition } & $\begin{array}{c}\text { Resid. Normality AD } \\
\text { statistic (P-Value) }\end{array}$ & $\begin{array}{c}\text { Resid. Constant } \\
\text { Variance P Value }\end{array}$ & $\begin{array}{c}\text { Resid. Indep. Dur- } \\
\text { bin-Watson statistic }\end{array}$ \\
\hline Cu.G.Cop.B & $0.678(0.037)$ & 0.060 & 2.4974 \\
Cu.G.Cop.R & $0.182(0.845)$ & 0.060 & 2.3095 \\
Cu.G.Cop.5 (Linear) & $0.846(0.012)$ & 0.059 & 1.9746 \\
Cu.G.Cop.5 (2 Segments) & $0.295(0.471)$ & 0.0600 & 1.7820 \\
Cu.G.Cop.8 & $0.118(0.974)$ & 0.060 & 1.1108 \\
Zn.P.St.B & $0.532(0.100)$ & 0.060 & 1.7010 \\
Zn.G.St.B & $0.292(0.481)$ & 0.060 & 1.8208 \\
Zn.P.St.R & $0.386(0.264)$ & 0.060 & 1.8546 \\
Zn.G.St.R & $0.328(0.350)$ & $\mathrm{N} / \mathrm{A}$ & 1.3176 \\
Zn.P.St.5 & $0.167(0.887)$ & 0.060 & 2.0350 \\
Zn.G.St.5 & $0.829(0.013)$ & 0.060 & 2.2657 \\
Zn.P.St.8 & $0.363(0.307)$ & 0.040 & 1.6505 \\
Zn.G.St.8 & $0.313(0.421)$ & 0.008 & 2.0137 \\
Pb.G.St.R & $0.384(0.267)$ & 0.060 & 1.40583 \\
Pb.P.St.5 & $0.858(0.011)$ & 0.060 & 2.2959 \\
Pb.G.St.8 & $0.203(0.772)$ & 0.060 & 2.3248 \\
\hline
\end{tabular}

$\mathrm{G}=$ gutter; $\mathrm{P}=$ pipe; $\mathrm{St}=$ steel Cop $=$ copper; $\mathrm{B}=$ bay waters; $\mathrm{R}=$ River waters; $5=\mathrm{pH} 5$ waters; $8=\mathrm{pH} 8$ waters 
Table 13.6 Two segment linear regression coefficients for copper releases under controlled $\mathrm{pH} 5$ conditions.

\begin{tabular}{ccccc}
\hline Metal, Pipe, Condition & $\begin{array}{c}\text { Coeff. y1 } \\
\text { (P-Value) }\end{array}$ & $\begin{array}{c}\text { Coeff. y2 } \\
\text { (P-Value) }\end{array}$ & $\begin{array}{c}\text { Coeff. y3 } \\
\text { (P-Value) }\end{array}$ & $\begin{array}{c}\text { Coeff. T1 } \\
\text { (P-Value) }\end{array}$ \\
\hline Cu.G.Cop.5 (2 Segments) & $1.6428(0.0013)$ & $2.7152(0.0007)$ & $2.4546(0.0002)$ & $1.0247(0.1059)$ \\
\hline
\end{tabular}

The time series of lead releases from steel gutters at $\mathrm{pH} 5$ and of steel pipes at $\mathrm{pH} 8$ were not fitted with linear equations due to initial lag periods before releases were observed. In the container with steel gutters at $\mathrm{pH} \mathrm{5,} \mathrm{no}$ lead was detected until after 1 month exposure: after 1 month exposure, the lead release reached $0.97 \mathrm{mg} / \mathrm{m}^{2}(0.02 \mathrm{mg} / \mathrm{L})$ and after 2 month exposure, the lead release exceeded $1 \mathrm{mg} / \mathrm{m}^{2}(0.028 \mathrm{mg} / \mathrm{L}$ to $0.037 \mathrm{mg} / \mathrm{L})$. There were only three detected lead concentrations in the data series. In the containers with steel pipe at $\mathrm{pH} 8$, lead releases were detected after 2 month exposure and exceeded $29 \mathrm{mg} / \mathrm{m}^{2}(0.71 \mathrm{mg} / \mathrm{L})$. Two concentration values above the detection limits were available.

Time series for copper releases from copper gutters under $\mathrm{pH} 5$ conditions showed an increase in the copper concentrations after $0.5 \mathrm{~h}$ exposure, and, after $27 \mathrm{~h}$ exposure, reached $970 \mathrm{mg} / \mathrm{m}^{2}(6.8 \mathrm{mg} / \mathrm{L})$. However, after $27 \mathrm{~h}$ exposure, copper concentrations levelled off. These copper data were therefore fitted using first order polynomial and two segment linear equations due to the obvious change in release rate after $27 \mathrm{~h}$. The numbers of data points in these time series were limited and the high concentration observed after $27 \mathrm{~h}$ exposure could have been an unusually high value. On the other hand, cupric ions could have been combined with the orthophosphate from the solution, thereby reducing copper solubility. Edwards (2002) observed that higher doses of orthophosphate tend to decrease solubility of copper.

The statistical software packages Minitab 16 (Minitab, Inc.) and Sigmaplot 11 (Systat Sofware, Inc.), were used to perform analyses and to check the assumptions. Pearson product moment correlations or Spearman rank order correlations were computed to determine if the data were significantly correlated at the 0.05 level. To investigate the goodness of model fit, residual plots were inspected to determine if the least squares assumptions for errors were met. To check the constant variance assumption, the plots of residuals vs the fitted values were inspected and the Levene median test was conducted to detect the differences in the variance values. To evaluate the normality of the residuals, normal probability plots and histograms of the residuals were also constructed. The Anderson-Darling test statistic was also calculated to check for normality. This test showed that all the data for regression analysis were normally distributed with the exception of lead releases from galvanized pipe under controlled pH 5 conditions (Table 13.4, above). The zero mean of the 
residuals assumption was checked by examining the descriptive statistics and graphs of the residuals vs fitted values and vs the order of the observations. To determine if the residuals were independent of each other, graphs of the residual vs observation number were examined and the Durbin-Watson statistic was calculated.

ANOVA tables were used to determine if the regression coefficients were not equal to zero and were statistically significant, and to evaluate if the overall regression equations were significant. The coefficient of determination $\left(R^{2}\right)$ was also calculated for each regression.

The residuals for most of the regression equations met the assumptions of normality, constant variance, zero mean and independence. $\mathrm{P}$ values for some regression analyses were lower than desired ( $\mathrm{P}$ values ranged from 0.04 to 0.008 , as shown in Table 13.4 above) which could have been explained by the fact that there were few data observations available for some conditions. The examination of the residual values vs fitted values for some of the samples showed that there was more spread in the residuals for the higher fitted values, but the assumption of the constant variance of the residuals was not rejected because of the few data points available. The Spearman rank correlations between the absolute values of the residuals and the observed value of the dependent variable were calculated to test the assumption of constant variance, which may be violated if the Spearman rank correlation was statistically significant. Levene's test was also used to determine if the residuals have constant variance. The results of Levene's test showed that the assumption of equal variance was met for most of the data, and for the rest of the time series the hypothesis of equal variances was not rejected due to the limited data. The results of the Durbin-Watson statistic indicated that the majority of the residuals were independent from each other (the Durbin-Watson statistic was in the range 1.5 to 2.5 ), and for the remaining data the hypothesis of independent residuals was not rejected because of the few data points.

The majority of the models had histograms of the residuals that were approximately bell shaped; the residuals were normally distributed and had zero mean, and were independent of each other.

In the ANOVA tests of the regression equations, the significance of the regression coefficients is strongly affected by the number of data observations. A high $R^{2}$ value can be observed with insignificant equation coefficients if there are only a few data available, such as in the time series of copper released from copper gutters under $\mathrm{pH} 5$ conditions. An important and strong association may not appear to be significant if there are only a few data observations available (Berthouex and Brown, 2002).

The standard error of the estimate was used to evaluate the ability of the model to predict (rather than relying only on $R^{2}$ ). Using the model, the 
standard error of the estimate was calculated using the variance of the predicted values, and was found to be a more precise indicator of the capability of the model to accurately predict dependent variables (Burton and Pitt, 2002).

Fitted Line Plot. Zn.G.St. B

logZn.G.St.B = $1.435+0.4383 \log$ Time

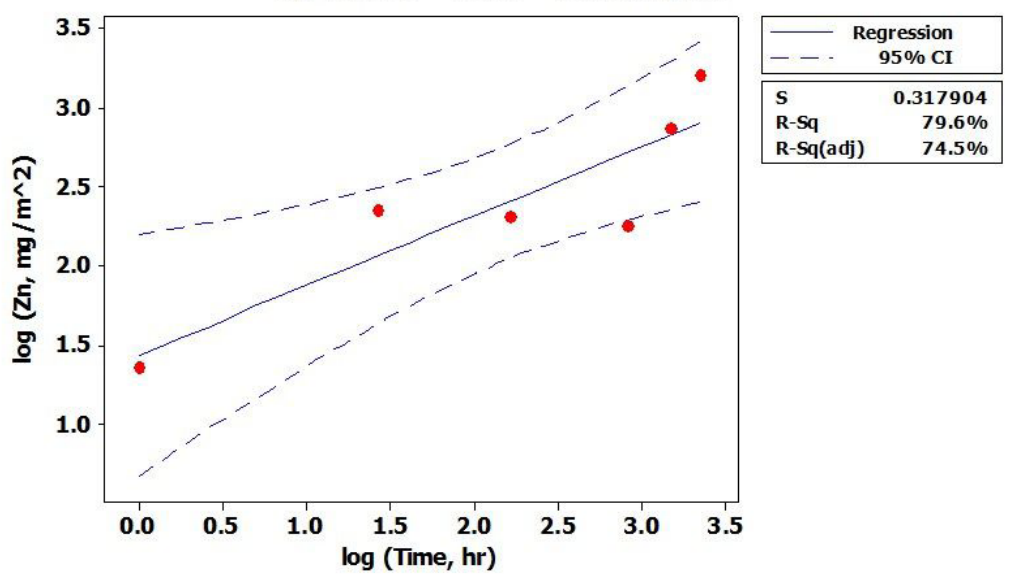

\section{Residual Plots for logZn.G.St.B}

Normal Probability Plot of the Residuals

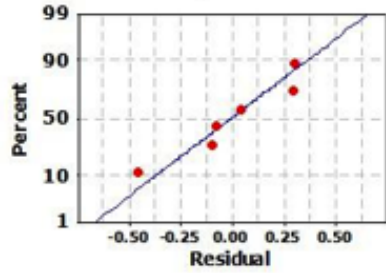

Histogram of the Residuals

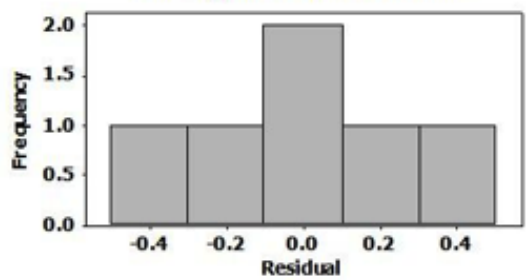

Residuals Versus the Fitted Values

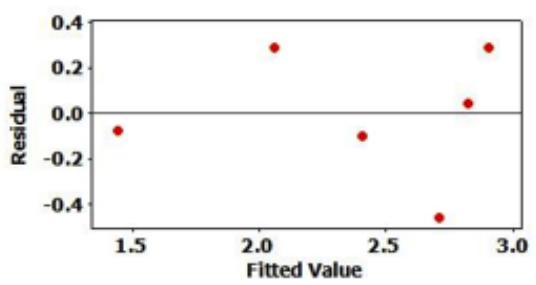

Residuals Versus the Order of the Data

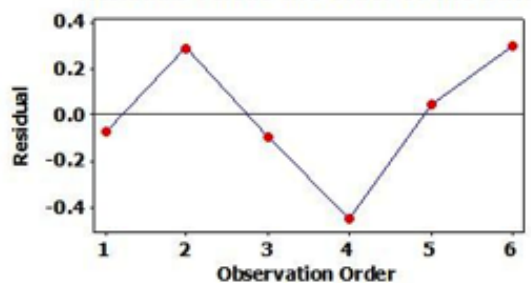

Figure 13.21 Empirical estimation (linear equation) of zinc release from galvanized steel gutter section submerged into bay waters as a function of time (Ogburn, 2013). 
For all of the regression equations, the constant term (intercept) was significant, with an exception for zinc releases from galvanized steel gutters in river water $(\mathrm{P}$ value $=0.079)$, and therefore in this case the regression was done without the intercept term. Additionally, ANOVA tables indicated that the slope terms were significant for all regression equations. The regression analysis results for zinc and lead releases from galvanized materials and copper releases from copper materials under controlled and natural $\mathrm{pH}$ conditions are shown in Table 13.4 and Table 13.5 above. An example set of plots is shown in Figure 13.21 above, a linear regression of zinc losses from a galvanized steel gutter sample submerged in bay water vs exposure time.

\subsection{Conclusions}

Some gutter and pipe materials can release large amounts of zinc, copper, and lead under controlled and natural $\mathrm{pH}$ and salinity conditions during both short and long exposure periods. Galvanized steel materials were the most significant source of lead and zinc, while copper materials were the greatest source of copper.

The greatest copper concentrations were detected in copper gutter samples. During short exposure periods, only copper materials were a source of copper under both high and low $\mathrm{pH}$ conditions during the controlled $\mathrm{pH}$ experiments. Under natural $\mathrm{pH}$ conditions, copper concentrations were detected only for copper materials during both short and long exposure times and exceeded $35 \mathrm{mg} / \mathrm{L}$ in bay samples after 3 month exposure. Concrete pipes were not a source of copper under either controlled or natural $\mathrm{pH}$ conditions. Other than for the concrete tests, the smallest copper concentrations were found during the HDPE, vinyl, galvanized and aluminum sample exposure tests during controlled $\mathrm{pH}$ conditions.

The greatest sources of zinc were galvanized steel materials. Zinc releases from galvanized steel materials were detected during both short $(0.5 \mathrm{~h}$ to $27 \mathrm{~h}$ ) and long exposure times (1 month to 3 month). Under controlled $\mathrm{pH}$ conditions, zinc releases in the samples with galvanized steel materials were greater and more rapidly released at higher $\mathrm{pH}$ values during long exposure time materials. The smallest sources of zinc were concrete and plastic materials.

Lead concentrations were released only from galvanized steel materials, but were released during both short and long exposure times and for both controlled and uncontrolled $\mathrm{pH}$ tests and high and low salinity conditions.

The highest aluminum concentrations were found during tests using aluminum materials. 
For controlled $\mathrm{pH}$ conditions, the largest concentrations of iron ( $>20 \mathrm{mg} / \mathrm{L}$ at $\mathrm{pH} 5$ ) were found to be leaching from galvanized steel materials. During natural $\mathrm{pH}$ conditions, concrete and galvanized steel materials were the greatest sources of iron.

Concrete, HDPE, and vinyl materials had little or no detected metal releases during both short and long term exposure times and therefore can be safely used as drainage system components or storage tanks materials. The use of copper materials for gutter systems is not advised due to high copper releases under a wide range of $\mathrm{pH}$ values and also in the presence of chloride ions. The use of galvanized materials should be avoided for drainage systems, and especially for storage tank materials, due to the substantial zinc releases under all water conditions.

The metal releases from naturally aged materials have been previously investigated (Clark et al., 2007; Lasheen et al., 2008; Good, 1993; Zobrist, 2000; Davis and Burns, 1999). These other studies indicated that aged materials and their coatings continue to leach significant amounts of metals into the environment during the material's service life.

\section{Acknowledgments}

The authors would like to thank the National Science Foundation EPSCoR program and the USEPA for partial financial support of this research.

\section{References}

Al-Malack, Muhammad H. 2001. Migration of lead from unplasticized polyvinyl chloride pipes. Journal of Hazardous Materials. B82 (2001) 263-274.

Berthouex, P.M. and L.C. Brown. 2002. Statistics for Environmental Engineers, 2nd Edn. Lewis Publishers, Boca Raton, FL. ISBN 1-56670-592-4.

Boulay, N., M. Edwards, Role of temperature, chlorine, and organic matter in copper corrosion by-product release in soft water, 2001. Water Res. 35 (2001) pp. 683-690.

Burton, G. Allen, Jr., Pitt, Robert E. 2002. Stormwater Effects Handbook: A Toolbox for Watershed Managers, Scientists, and Engineers. Lewis Publishers. A CRC Press LLC. ISBN 0-87371-924-7.

Clark, Shirley E., Franklin, Kelly A., Hafera, Julia M.and Kirby, Jason T. 2007. Roofing as a contributor to urban runoff pollution. World Environmental and Water Resources Congress 2007:Restoring Our Natural Habitat. ASCE/EWRI, Tampa, FL, May 1519, 2007. CD-ROM.

Clark, Shirley E., Long, Brett V., Siu, Christina Y.S., Spicher, Julia and Steele, Kelly A. 2008. Runoff Quality from Roofing during Early Life. Accepted for publication in the Low Impact Development 2008 Conference Proceedings, Seattle, WA, November 16 - 19, 2008. American Society of Civil Engineers, Reston, VA. CD-ROM. 
Clark, Shirley E., Steele, Kelly A., Spicher, Julia, Siu, Christina Y.S., Lalor, Melinda M., Pitt, Robert E. and Kirby, Jason T. 2008. Roofing Materials'Contributions to StormWater Runoff Pollution. Journal of Irrigation and Drainage Engineerigng.Vol.134, No. 5, October 1, 2008.

Corvo, F., J. Minotas, J. Delgado and C. Arroyave. 2005. Changes in atmospheric corrosion rate caused by chloride ions depending on rain regime. Corrosion Science Vol. 47(4): 883-892.

Davis, A. and M. Burns, 1999. Evaluation of lead concentration in runoff from painted structures. Water Research. 33(13): 2949-2958, 1999.

Degremont. 1979. Water Treatment Handbook. 5th edition. A Halsted Press Book. John Willey \& Sons, Inc. New York., 1979. ISBN:0470-26749-6.

Edwards, M, Loay Hidmi, Dawn Gladwell, 2002. Phosphate Inhibition of Soluble Copper Corrosion By-Product Release. Corrosion Science, accepted 14 June 2001; 44, 2002, pp. 1057-1071

Edwards,M., K. Powers, L. Hidmi, M.R. Schock, 2001. The role of pipe aging in copper corrosion by-product release, Water Sci. Technol.: Water Supply Vol.1, No.3, 2001, pp. 25-32.

Edwards M., Schock M. R. and Meyer T.,1996. Alkalinity, pH and copper corrosion byproduct release. J. AWWA, 1996, 88(3), 81.

Faller, M. and Reiss, D. 2005. Runoff Behavior of Metallic Materials Used for Roofs and Facades - A Five Year Exposure Study in Switzerland. Materials and Corrosion 2005, 56, No. 4.

Förster, J. 1996. Patterns of roof runoff contamination and their potential implications on practice and regulation of treatment and local infiltration, Water Sci. Tech, Vol. 33, No. 6, 1996, pp. 39-48.

Gabriel, Lester, H., Eric T. Moran, 1998. NCHRP Synthesis 254. Service life of Drainage Pipe. A Synthesis of Highway Practice. Transportation Research Board. Notional Research Council. National Cooperative Highway Research Program. National Academy press, Washington, D.C. 1998.

Garrels, Robert M. and Christ, Charles L. 1990. Solutions, Minerals, and Equilibria. Jones and Bartlett Publishers, Inc., Boston, MA.

Good, J.C., 1993. Roof Runoff as a Diffuse Source of Metals and Aquatic Toxicity in Storm Water. Water Science and Technology. Vol. 28, No3, 1993.

Gromaire, M.C., Chebbo, G. and Constant, A. 2002. Impact of zinc roofing on urban runoff pollutant loads: The case of Paris. Water Science and Technology, 45(7), 113-122. 2002 .

He, W. 2002. Atmospheric Corrosion and Runoff Processes on Copper and Zinc as Roofing Materials. Doctoral thesis, Royal Institute of Technology, Stockholm, Sweden, ISBN 91-7283- 364-5.

He, W., I. Odnevall Wallinder and C. Leygraf. 2001a. A laboratory study of copper and zinc runoff during first flush and steady-state conditions, Corrosion Science 43 (2001) 127-146.

He, W., I. Odnevall Wallinder and C. Leygraf. 2001b. A comparison between corrosion rates and runoff rates from new and aged copper and zinc as roofing material, Corrosion Science 1 (2001) 67-82. 
Horvath, Adrienn. 2011. Roof Runoff Quality and Reduction Possibility of the Pollutants. Pollack Periodica: An International Journal for Engineering and Information Sciences DOI: 10.1556/Pollack.6.2011.1.10 Vol. 6, No. 1, pp. 107-116 (2011) HU ISSN 1788-1994 (C) 2011 Akadémiai Kiadó, Budapest

Klinskiy G.D., Skopinzev V.D., 2001. Inorganic Chemistry for Biologists. Publisher MCXA, Moscow. 2001. ISBN 5-94327-031-0

Langmuir, Donald, 1997. Aqueous Environmental Geochemistry. Prentice Hall, Inc. Upper Saddle River, New Jersey. 1997. ISBN 0-02-367412-1

Lasheen, M.R., C.M. Sharaby, N.G. El-Kholy, I.Y. Elsherif and S. T. El-Wakeel. 2008. Factors influencing lead and iron release from some Egyptian drinking water pipes. Journal of Hazardous Materials. 160 (2008) 675-680.

Lagos, G.E., C.A. Cuadrado, M.V. Letelier, 2001. Aging of copper pipes by drinking water, J. Am. Water Works Assoc. Vol. 93, No.11, 2001, pp. 94-103.

Merkel, T.H, H.-J. Groß, W. Wernera, T. Dahlkeb, S. Reichertera, G. Beuchleb, S.H. Eberle, 2002. Copper corrosion by-product release in long-term stagnation experiments, Water Research, Vol. 36, Issue 6, 2002. pp. 1547-1555.

Mansouri, M.R., H. Pour Moghadas, G. Sahmskhorraabadi, 2003 A study of leakage of trace metals from corrosion of the municipal drinking water distribution system. Journal of Research in Medical Sciences, Vol 8, No 3, 2003.

Morquecho, Renee E. 2005. Pollutant Associations with Particulates in Stormwater. A dissertation. Tuscaloosa, Alabama.

NRC (National Research Council). 2008. Report of the NRC: Urban Stormwater Management in the United States. The National Academies Press. Washington, D.C. Committee on Reducing Stormwater Discharge Contributions to Water Pollution, Water Science and Technology Board, Division on Earth and Life Studies, available at: http://www.nctcog.org/envir/SEEclean/stormwater/nrc_stormwaterreport.pdf. (Accessed February 18, 2012).

Odnevall Wallinder, I., Hedberg, Y. and Dromberg P. 2009. Storm Water Runoff Measurements of Copper From a Naturally Patinated Roof and From a Parking Space. Aspects on Environmental Fate and Chemical Speciation. Water Research 43 (2009)503150308

Odnevall Wallinder, I., Korpinen, T., Sundberg, R. and Leygraf, C. 2002. Atmospheric corrosion of naturally and pre-patinated copper roofs in Singapore and Stockholm Runoff rates and corrosion product formation. ASTM Special Technical Publication: Outdoor Atmospheric Corrosion, 1421, 230-244. 2002

Odnevall Wallinder, I., Leygraf, C., Karlen, C., Heijerick, D. and Janssen C. R., 2001 Atmospheric Corrosion of Zinc-Based Materials: Runoff Rates, Chemical Speciation, and Ecotoxicity effects. Corros. Sci., 2001, 43, 809-916.

Odnevall Wallinder, I., Verbiest, P., He, W. and Leygraf, C. 2000. Effects of Exposure Direction and Inclination on the Runoff Rates of Zinc and Copper Roofs. Corrosion Science 42 (2000)1471-1487.

Ogburn, Olga N. L., 2013. Urban Stormwater Runoff Contamination Associated with Gutter and Pipe Material Degradation. A dissertation. Tuscaloosa, Alabama.

Pehkonen, S.O., A. Palit, X. Zhang, Effect of specific water quality parameters on copper corrosion, 2002. Corrosion 58 (2002) pp.156-165. 
Pitt, R. 1995. Water Quality Trends from Stormwater Controls. Stormwater NPDES Related Monitoring Needs; Proceedings of an Engineering Foundation Conference, 1995 p 413-434. Edited by H.C. Torno, New York, N.Y.; ASCE.

Schock, D.A. Lytle, J.A. Clement, 1995. EPA/600/R-95/085, US Environmental Protection Agency, Washington, DC, 1995.

Shreir, L.L. 1976. Corrosion. Volume 1. Metal/Environment Reactions. Newnes-Butterworths. London, Boston. ISBN 0-408-00109-7.

Tobiason, Scott. 2004. Stormwater Metals Removal by Media filtration: Field assessment Case Study. Watershed 2004; specialty conference; onlite program; Hyatt Regency Dearbon, Michigan, USA, July 11-14, 2004.

US EPA, 2007. Aquatic Life Ambient Freshwater Quality Criteria - Copper. Publication No. EPA/822/R-07/001.

US EPA, 1995. Schock, M.R. and D.A. Lytle. Effect of pH, DIC, Orthophosphate and Sulfate on Drinking Water Cuprosolvency. Publication No. EPA/600/R-95/085.

US EPA. National Recommended Water Quality Criteria. Available at: http://water.epa. gov/scitech/swguidance/standards/criteria/current/index.cfm. (Accessed October 21, 2012)

Veleva L., Meraz, E. and Acosta, M. 2010. Zinc precipitation runoff from galvanised steel in humid tropical climate. Corrosion Engineering, Science and Technology. 2010, Vol. 45 (1).

Zobrist, J., Muller, S. R., Ammann, A., Bucheli, T. D., Mottier, V., Ochs, M., Schoenenberger, R., Eugster, J., and Boller, M., 2000. Quality of Roof Runoff for Groundwater Infiltration. Water. Res., 2000, Vol.34, No.5, p. 1455-1462. 